This item was submitted to Loughborough's Research Repository by the author.

Items in Figshare are protected by copyright, with all rights reserved, unless otherwise indicated.

\title{
Growth volatility and inequality in the U.S.: A wavelet analysis
}

PLEASE CITE THE PUBLISHED VERSION

https://doi.org/10.1016/j.physa.2019.01.024

PUBLISHER

(c) Elsevier

VERSION

AM (Accepted Manuscript)

PUBLISHER STATEMENT

This paper was accepted for publication in the journal Physica A: Statistical Mechanics and its Applications and the definitive published version is available at https://doi.org/10.1016/j.physa.2019.01.024.

\section{LICENCE}

CC BY-NC-ND 4.0

\section{REPOSITORY RECORD}

Chang, Shinhye, Rangan Gupta, Stephen M. Miller, and Mark Wohar. 2019. "Growth Volatility and Inequality in the U.S.: A Wavelet Analysis". figshare. https://hdl.handle.net/2134/37370. 


\title{
Growth Volatility and Inequality in the U.S.: A Wavelet Analysis
}

\author{
Shinhye Chang ${ }^{*}$, Rangan Gupta ${ }^{* *}$, Stephen M. Miller ${ }^{* * *}$ and Mark E. Wohar ${ }^{* * * *}$
}

\begin{abstract}
This study applies wavelet coherency analysis to explore the relationship between the U.S. economic growth volatility, and income and wealth inequality measures over the period 1917 to 2015 and 1962 to 2014 . We consider the relationship between output volatility during positive and negative growth scenarios. Wavelet analysis simultaneously examines the correlation and causality between two series in both the time and frequency domains. Our findings provide evidence of positive correlation between the volatility and inequality across high (short-run)- and low-frequencies (long-run). The direction of causality varies across frequencies and time. Strong evidence exists that volatilities lead inequality at low-frequencies across income inequality measures from 1917 to 1997. After 1997, however, the direction of causality changes. In the time-domain, the time-varying nature of long-run causalities implies structural changes in the two series. These findings provide a more thorough picture of the relationship between the U.S. growth volatility and inequality measures over time and frequency domains, suggesting important implications for policy makers.
\end{abstract}

Keywords: Growth volatility, Income and Wealth Inequalities, Wavelet analysis

JEL Classification: C49, O15

\footnotetext{
* Department of Economics, University of Pretoria, Pretoria, 0002, South Africa. Email: c.shin.h@gmail.com. ** Department of Economics, University of Pretoria, Pretoria, 0002, South Africa. Email: rangan.gupta@up.ac.za. ${ }^{* * *}$ Corresponding author. Department of Economics, Lee Business School, University of Nevada, Las Vegas, 4505 Maryland Parkway, Box 456005, Las Vegas, NV 89154-6005, USA. Email: stephen.miller@unlv.edu.

**** College of Business Administration, University of Nebraska at Omaha, 6708 Pine Street, Omaha, NE 68182, USA; School of Business and Economics, Loughborough University, Leicestershire, LE11 3TU, UK. Email: mwohar@unomaha.edu.
} 


\section{$1 \quad$ Introduction}

Does growth volatility affect income/wealth inequality? Ramey and Ramey (1995) examine the relationship between output growth and its volatility. They find an inverse relationship between output volatility and the output growth rate. Their results raise the question of whether volatility also affects other macroeconomic variables. Hausmann and Gavin (1996) investigate the relationship between volatility and inequality, finding adverse effects of income volatility on the distribution of income. How does volatility affect the inequality?

Theory suggests several channels to explain how growth volatility affects the distribution of income. Volatility can affect the income distribution as individuals possess different levels of risk tolerance and the channels of influence on inequality relate to risk. First, entrepreneurs exhibit higher levels of risk tolerance than salary earners. Also, bearing risk enables entrepreneurs to capture the resulting higher risk premium that contributes to their income and wealth. Caroli and García-Peñalosa (2002), focusing on this wage channel, consider an economy where random shocks affect output and, in turn, wages fluctuate. They argue that the share of output captured by entrepreneurs becomes larger the more volatile the output because salaried workers will take a decreased salary to get a constant wage.

Second, Checchi and García-Peñalosa (2004), considering the human capital channel, examine the effects of wage volatility on wage differentials between low and high skilled workers. They find that high wage volatility causes a high degree of educational inequality and, as a result, income inequality rises.

Third, volatility makes economic growth less favourable to the poor. Low-income groups do not experience good access to financial and credit markets. These market imperfections can influence occupational outcomes of low-income individuals. Also, they depend more on state grants and social services (Jeanneney and Kpodar 2011). The poor receive less diversified sources of income, possess inferior qualifications, and exhibit less 
mobility than the rich (Galor and Zeira, 1993; Agénor, 2004; Laursen and Mahajan, 2005; Corak et al., 2014).

How can we explain the divergence in the patterns of output volatility and income inequality that the data support? Eksi (2017) shows that an increase in the time-series variance of micro income shocks lead to increases in both output and income inequality. Moreover, a decrease in the cross-sectional correlation of these shocks across individuals leads to a decrease in output volatility, but to an increase in income inequality. In other words, one variable is an increasing function of the correlation parameter, while the other is a decreasing function of it. Eksi (2017) argues that the simultaneity of the changes in output volatility and income inequality during the Great Moderation period is not a coincidence, but reflects the fact that the variables depend on the same parameters of the underlying income microdata.

Many empirical studies find that higher volatility associates with higher income inequality. Hausmann and Gavin (1996) find that Latin American countries display higher income inequality and much more volatile economic growth rates. Laursen and Mahajan (2005) find that output volatility negatively influences the equality of the income distribution of the bottom $20 \%$ income group. With the cross-sectional data of the Gini coefficient and the income share of the top quintile of developing and developed countries, Breen and García-Peñalosa (2005) show that higher growth volatility links to higher income inequality.

Numerous empirical studies exist that use panel data. Using a panel data set of 70 countries from 1960 to 2002, Konya and Mouratidis (2006) find that volatility affects inequality, but that inequality does not exert a direct effect on volatility. They also find that low growth volatility reduces inequality, whereas high growth volatility leads to more unequal income distribution. In other words, growth volatility reduces inequality in countries with low volatility, while it increases income inequality in countries with high volatility. Calderón and Yeyati (2009) use a panel data set of 75 countries over 1970-2005 and also find that output 
volatility increases income inequality, especially with extremely high volatility, such as macroeconomic crises. They conclude that volatility increases the income share of the highest quintiles at the expense of the middle $40 \%$. Using annual data from the 48 U.S. states over 1945-2004, Huang et al. (2015) find robust results that larger growth volatility positively and significantly associates with higher income inequality. Chauvet et al. (2017) also examine the relationship between income volatility and inequality, considering aid and remittances. The authors employ a panel of 142 countries over 1973-2012 and find that volatility increases inequality, where lower income groups are most exposed to the volatility. They also find robust evidence suggesting that aid helps to reduce the negative effects of volatility on the distribution of income.

The effect of output volatility on inequality is well-documented in the literature and most of the studies find that volatility produces an unfavourable effect on the distribution of income. Studies also suggest, however, a possibility of income inequality intensifying macroeconomic volatility. Alesina and Perotti (1996) argue that income inequality exerts an indirect effect on macroeconomic volatility via increased political instability. Aghion, et al. (1997) and Aghion, et al. (1999) argue that inequality in the form of unequal access to investment opportunities combined with a high level of capital market imperfection may generate persistent credit cycles, resulting in output and investment volatility. Levy (2002) uses an AS-AD model and theoretically shows income inequality may influence macro-economic variables by affecting the money multiplier and the trade-off between inflation and output.

One study considers the short- and long-run effects of income volatility on inequality. Bahmani-Oskooee and Motavallizadeh-Ardakani (2018) employ linear and nonlinear ARDL approaches on annual U.S. state panel data from 1945 to 2013 and discover short-run asymmetric effects of income volatility on a measure of inequality in many states. The shortrun effects translate to long-run asymmetric effects, however, in nineteen states. Only one state, 
South Dakota, shows long-run symmetric effect wherein increased volatility worsens inequality and decreased volatility improves it. The authors also find that both increased volatility and decreased volatility can create unequalizing effects on income distribution in only Indiana, Michigan and Wyoming and conclude overall that, in the United States, reducing income or output volatility will not help to reduce income inequality.

Given the conclusions in the existing literature, our paper provides three main contributions. First, we extend the existing literature on the effects of income and wealth inequality on output volatility, combining time-series and frequency-domain analyses. Wavelet analysis allows us to examine the time-frequency historical effects of volatility on U.S. income and wealth inequality. Using wavelet coherency, we can assess the role of income and wealth inequality on growth volatility dynamics at different frequencies and specific moments in time. At the same time, we can indicate the direction of the causality between inequality and volatility at different moments in time. The time- and frequency-varying relationships can provide significant implications for macroeconomic policymakers. The time-varying relationships indicate that the variables influence each other differently at different points in the business cycle (Li et al. 2015). Frequency-varying relationships reveal short- versus long-term linkages between two variables. In addition, unlike standard tests of Granger causality that require pretesting for unit roots and cointegration, wavelet analysis provides robust evidence in favour of or against causal relationships between variables under consideration without accounting for issues associated with stationary or non-stationary data and the existence or non-existence of long-run relationships. In other words, we can work with the raw data and do not need to transform the data, which, in turn, often tends to change the definition of the original variables for which we are trying to detect causal relationships.

Second, in contrast to the bulk of the literature that uses output volatility defined as the standard deviation of the rate of output growth, we use the realized volatility calculated by 
taking the sum over the squared quarterly GNP growth rates. Realized volatility is a nonparametric, ex-post estimate of the return (growth) variation and it provides empirical content to the latent variance variable (Andersen and Teräsvirta 2009). Therefore, this approach proves useful for specification testing of the restrictions imposed on volatility by parametric models previously estimated with low-frequency data. Further, realized volatility measures facilitate direct estimation of parametric models. ${ }^{1}$

Finally, we not only examine the aggregate growth volatility but also investigate the volatility related to positive growth (i.e. good volatility) and the volatility connected to negative growth (i.e. bad volatility), which allows deeper examination on the different aspects of volatilities.

Our results show that co-movements between volatility and inequality appear in the short- and long-run and that the direction of causality evolves with time and frequency. The rest of the paper is organized as follows. Section 2 presents the methodology. Sections 3 and 4 present the data and the empirical results, respectively. Section 5 concludes the paper.

\section{Methodology: Wavelet Coherency and Phase Difference}

Wavelet analysis allows the extraction of time- and frequency-localized information, which permits deeper investigation of the causality between variables (Roueff and Sachs 2011). Economic processes emerge as outcomes of the actions of numerous agents at different frequencies, which implies that a macroeconomic time series incorporates information that operates at different time domains. Wavelet analysis separates the time series into several subseries, which may associate with a particular time domain and which narrows the focus to provide fruitful insights on economic phenomena (Ramsey and Zhang 1996, 1997). Moreover, we can apply wavelet analysis to non-stationary and locally stationary as well as series with structural breaks (Roueff and Sachs 2011).

\footnotetext{
${ }^{1}$ Please see Andersen and Teräsvirta, 2009 for detailed discussion on realized volatility
} 
Hudgins et al. (1993) and Torrence and Compo (1998) develop methodologies of the cross-wavelet power, the cross-wavelet coherency, and the phase difference. Wavelet analysis closely links to Fourier analysis; but, it possesses certain advantages. Wavelet analysis conserves information in both time and frequency domains by conducting the estimation of spectral characteristics of a time series as a function of time (Aguiar-Conraria et al. 2008). Also, wavelet analysis applies to non-stationary or locally stationary series (Roueff and Sachs 2011). Wavelet coherency involves a three-dimensional analysis, which counts the time and frequency elements at the same time as well as the strength of the correlation between the timeseries elements (Loh 2013). Thus, we can observe both the time- and frequency-variations of the correlation between two series in a time-frequency domain. When the frequency components exhibit non-stationarity, the traditional approach may miss such frequency components. Wavelet analysis provides the time- and frequency-localized information with structural breaks. Thus, we can avoid the need to assume stationarity (Fan and Gençay 2010).

As a result, wavelet coherency delivers a better measure of the co-movement between variables, U.S. income and wealth inequality and output volatility, in comparison to conventional causality and correlation analysis. Following the approach of Li et al. (2015), we estimate wavelet coherency by using the cross-wavelet and auto-wavelet power spectrums as follow:

$$
R_{x y}^{2}(\tau, s)=\frac{\left|S\left(s^{-1} W_{x y}(\tau, s)\right)\right|^{2}}{S\left(s^{-1}\left|W_{x}(\tau, s)\right|^{2}\right) S\left(s^{-1}\left|W_{y}(\tau, x)\right|^{2}\right.}
$$

where complex argument $\arg W_{x y}(\tau, s)$ is the local relative phase between $x_{t}$ and $y_{t}$, $\left|W_{x}(\tau, s)\right|^{2}$ represents the wavelet power, $\arg W_{x}(\tau, s)$ is local phase, and $S$ represents a smoothing operator. ${ }^{2}$ The ratio of the cross-wavelet spectrum to the product of the spectrum of

\footnotetext{
${ }^{2}$ Without smoothing, the squared wavelet coherency is always equal to 1 at any frequency and time. Torrence and Compo (1998) show that smoothing in time or frequency increases the degrees of freedom of each point and increases the confidence of the wavelet spectrum.
} 
each series equals the local correlation of the two series. This formula gives a quantity between 0 and 1 in a time-frequency window. Zero coherency indicates that no co-movement occurs between the volatility, and the income and wealth inequality measures, while the highest coherency implies the strongest co-movement between the two series. On the wavelet coherency plots, red and blue colours correspond to strong and weak co-movements, respectively.

As the wavelet coherency is squared, we cannot easily distinguish between positive and negative co-movements. Rather, we use the phase difference to provide information on positive and negative co-movements as well as the lead-lag relationships between the two series. ${ }^{3}$ Bloomfield et al. (2004) characterize the phase difference relationship between $x(t)$ and $y(t)$ such that:

$$
\phi_{x y}=\tan ^{-1}\left(\frac{\mathcal{J}\left\{s\left(s^{-1} W_{x y}(\tau, s)\right)\right\}}{\Re\left\{S\left(s^{-1} W_{x y}(\tau, s)\right)\right\}}\right) \text {, with } \phi_{x y} \in[-\Pi, \Pi] \text {, }
$$

where $\mathcal{J}$ is the imaginary part of the smoothed cross-wavelet transform and $\mathfrak{R}$ represents the real part of the smoothed cross-wavelet transform.

A phase difference of zero reveals that the two underlying series move together, while a phase difference of $\pi(-\pi)$ indicates that the two series move in the opposite directions. If $\phi_{x y} \in(0, \pi / 2)$, then the series move in phase (positively co-move) with $y(t)$ leading $x(t)$. If $\phi_{x y} \in(\pi / 2, \pi)$, then the series move out of phase (negatively co-move) with $x(t)$ leading $y(t)$. If $\phi_{x y} \in(-\pi,-\pi / 2)$, then the series move out of phase with $y(t)$ leading $x(t)$. Finally, if $\phi_{x y} \in(-\pi / 2,0)$, then the series move in phase with $x(t)$ leading $y(t)$. Also, the phase difference indicates causality between $x(t)$ and $y(t)$ in both the time and frequency domains. Overall, wavelet analysis enables a deeper understanding than the conventional causality test, which assumes that a single causal link holds for the whole sample period as well as at each

\footnotetext{
${ }^{3}$ The term phase means the position in the pseudo-cycle of the series as a function of frequency.
} 
frequency (Grinsted et al. 2004; Tiwari et al. 2013). For instance, in wavelet analysis, if $x(t)$

leads $y(t)$, then a causal relationship runs from $x(t)$ to $y(t)$ at a particular time and frequency

(Li et al. 2015).

\section{$3 \quad$ Data}

The U.S. economy experienced several episodes of high and low growth volatility, such as low volatility of output from the mid-1980s up to 2008 (called the Great Moderation), and increased growth volatility characterizing the late 1960s and 1970s (called the Great Inflation) and from 1929 to the start of World War II (Great Depression). In addition, movements in inequality conform to certain periods of time, including 1945 to 1979 (called the Great Compression) and 1980 to the present (called the Great Divergence). Our analysis provides clarification on the causality between income and wealth inequality and growth volatility, at different frequencies and at a different moments in time. We use data with an annual frequency covering 1917 to 2015 for volatility and income inequality and 1962 to 2014 for volatility and wealth inequality. Data for the quarterly real GNP over 1917Q1 to 2015Q2 come from Omay et al. (2017) ${ }^{4}$ and from the Federal Reserve Economic Data (FRED) of the Federal Reserve Bank of St. Louis from 2015Q3 to 2015Q4. Using quarterly GNP data, we calculate the annual realized volatility by taking the sum of quarterly squared growth rates. In our analysis, we not only use output volatility but we also categorize it into positive/good and negative/bad volatilities. We first

\footnotetext{
${ }^{4}$ The authors explain how they compute the unique dataset, which is the longest possible data on U.S. output available at a quarterly frequency (i.e., the most relevant frequency at which to measure output globally). First, the observations covering the period 1875:Q1-1946:Q4 used by Omay et al., (2017) (and in our case 1917:Q11946:Q4) come from National Bureau of Economic Research (NBER), available for download at: http://www.nber.org/data/abc/, with the actual sources being the tables of quarterly data corresponding to Appendix B of Gordon (1986). As Omay et al., (2017) point out, this is the only existing source for the pre-1947 quarterly data on U.S. GNP and the GNP deflator with National Income and Product Account (NIPA) quarterly data series non-existent before 1947. Second, Omay et al., (2017) use data from 1947:1-2015:2 from the FRED database. Note that the dataset compiled by Gordon (1986) runs through 1983:4 with 1972 as the base year of the GNP deflator. Given that nominal GNP and the GNP deflator data based on the NIPA are available from 1947:1, Omay et al., (2017) decided to use, for those variables, the FRED database, rather than the Gordon (1986) one, which, in any case, only runs through 1983:4. Omay et al., (2017) updatethe base year of the GNP deflator for the period 1875:1-1946:4 from 1972 to 2009 to correspond to the base year of the GNP deflator based on the NIPA. Thus, the real GNP is ultimately in constant 2009 prices.
} 
create dummy variable, 1 for positive quarterly growth rate of output and 0 otherwise, and multiply the growth rate with the dummy variable. We do the same as above for the cases of negative quarterly growth rates. Then we take sum of the squared positive or negative quarterly growth rates of output over a specific year to obtain a measure of good or bad realized volatility respectively. . Income inequality measures - Atkinson Index, Gini Coefficient, the Relative Mean Deviation, Theil's entropy Index, Top 10\%, Top 5\%, Top 1\%, Top 0.5\%, Top 0.1\%, and Top $0.01 \%{ }^{5}$ - come from the online data segment of Professor Mark W. Frank's website. ${ }^{6}$ Wealth inequality measures - Top 10\% net personal wealth (p90p100), Middle 40\% (p50p90), Bottom 50\% (p0p50), and Top 1\% (p99p100) - come from World wealth and income database (WID) with data range from 1962 to $2014 .{ }^{7}$ We employ the frequency cycles in the analysis. The first cycle (1-2-years cycle) associates with the short-run, or with high-frequency bands. The second cycle (2-4-years cycle) associates with the long, or with low frequency bands.

\section{$4 \quad$ Main analysis}

We simultaneously look at the correlation and the causal relationship between (i) income and wealth inequality, and growth volatility (ii) income and wealth inequality, and positive volatility, and (iii) income and wealth inequality, and negative volatility.

The results of wavelet coherency indicate correlation between two variables. The wavelet coherency between volatility and the various income inequality measures show statistically significant high coherency across high- and low-frequencies in Fig. 1. Across the high- and low-frequency bands, at least two significant islands exist of high coherency between output volatility and the income inequality measures. With the wealth inequality measures in Fig 4, we observe the consistent strong positive correlation between growth volatility and

\footnotetext{
${ }^{5}$ Top income shares serve as useful proxies for inequality across the income distribution (Leigh 2007).

${ }^{6} \mathrm{See}$ http://www.shsu.edu/eco mwf/inequality.html. Professor Frank constructed the dataset based on the Internal Revenue Service (IRS) information, which has a limitation of omission of some individual earning less than a threshold level of gross income. For this reason, we focus more on top income shares as primary indicators of inequality measures.

${ }^{7}$ The data is available for download from: http://wid.world/.
} 
inequality measures at the 2-4 years frequency. Only weak correlation appears with wealth inequality measures across the 1-2 year frequency.

The coherency results of positive volatility and income inequality measures also show statistically significant high coherency islands over the short- and long-term in Fig. 2. Especially from 1917 to the 1960s, all income inequality measure indicate strong co-movement across low-frequency. Only weak correlation appears with top income shares across highfrequency band from 1935 to 1997 and with wealth inequality measures across low frequencies in Fig. 5. Compared to the aggregate output volatility, positive volatility shows less strong comovement with top income shares across high-frequency.

The results of negative volatility show statistically significant high coherency across 12 year frequency band for all inequality measures in Fig. 3. Across the 2-4 years frequency band, we observe a significant island from 1935-1961 and 1942-1963, which relates to World War II. Sign of strong correlation appears with the Top $1 \%$, Top $0.5 \%$, Top $0.1 \%$ and Top $0.01 \%$ of income inequality and with wealth inequality measures across high-frequency bands in Fig 6. Fig. 3 also shows stronger correlations between the negative volatility and inequality over the short-term than positive volatility. That is, negative volatility exerts a bigger effect on inequality than positive volatility over the short-term.

Our empirical evidence shows that volatility and inequality relate positively, which a number of studies show. This positive relationship appears in Hausmann and Gavin (1996), Breen and García-Peñalosa (2005), Laursen and Mahajan (2005), and Calderón and Yeyati (2009).

The phase differences of Figs. 1 to 6 indicate the causality between two series (see Fig. 7 for compiled results). Across the 2-4 year frequency band in Fig. 7, for all three volatility measures, volatility leads the income inequality measures. The change of direction of causality from volatility leads to inequality leads in the early 2000 s probably indicates a structural break. 
At low frequency, volatility leads the wealth inequality measures Top 10\% (p90p100) and Middle 40\% (p50p90) in 1962-2014, whereas Bottom 50\% (p0p50) and Top 1\% (p99p100) lead volatility. Negative volatility leads Top $10 \%$ and Top $1 \%$, whereas Middle $40 \%$ and Bottom 50\% lead negative volatility in 1962-2014. Positive volatility leads Top 10\% and Top $1 \%$ through the early 2000 s and the direction of causality changes after that. Positive volatility also leads Bottom 50\% through the late 1980s and the direction of causality changes after that. Middle 40\% leads positive volatility from 1962 through the late 1990s and causality changes after that. For Top $10 \%$ at low frequency, aggregate and negative volatility lead wealth inequality. Bottom 50\% leads aggregate and negative volatility from 1962 to 2014 .

Compared to long-term causality, more movement occurs in changes of direction of causality in the short-term. Volatility leads the Atkinson Index and the Relative Mean Deviation from 1917 to the late 1950s, while the Atkinson Index and the Relative Mean Deviation lead volatility after that. Volatility also leads the Gini coefficient and the Theil index from 1917 to the late 1950s and from the late 1980s to 2014, while the Gini coefficient and the Theil index lead volatility from 1961 to the late 1980s. The Top income shares, however, lead volatility, except in 1917-1921, when volatility leads Top 5\%, in 1917-1938, when volatility leads Top $0.1 \%$, and in $1917-1943$, when volatility leads Top $0.01 \%$. For high frequencies, the Top $0.1 \%$ leads positive volatility and Top $10 \%$ leads negative volatility from 1917 to 2015 . The direction of causality of the wealth inequality measures Top 10\% (p90p100) and Middle $40 \%(\mathrm{p} 50 \mathrm{p} 90)$ change in the mid and late 1970s. For Bottom 50\% (p0p50) and Top 1\% (p99p100), the direction of causality changes in the mid-2000s. The 1970s saw two oil price spikes, as OPEC began affecting prices. Also, the Vietnam War covered the 1967-1972 period, where, in turn, productivity growth slowed.

Similar to the causality with aggregate growth volatility, the direction of causality of the wealth inequality measures Top $10 \%$ and Middle $40 \%$ change in the mid and late 1970 s for 
positive volatility. The Top $10 \%$ leads positive volatility from 1917 to 1976 , while positive volatility leads Top 10\% from 1977 to 2014 . In contrast, Middle 40\% leads positive volatility from 1979 to 2014, while positive volatility leads Middle 40\% from 1962 to 1978 . Top 1\% leads positive volatility from 1917 to 1988 and positive volatility takes lead from 1989, whereas Bottom 50\% leads negative volatility in 1962-2014.

Top $1 \%$, Top $0.5 \%$, Top $0.1 \%$, and Top $0.01 \%$ income shares mostly lead positive volatility in our data range. Top $10 \%$ and Top 5\% show similar patterns and directions of causality. Positive volatility leads the Relative Mean Deviation, and the Theil index in 1917 through the 1960s and in the late 1980s through 2015, while the two measures of inequality lead positive volatility in the rest of period. Positive volatility leads the Gini coefficient from 1917 to 2015 except from 1979 to 1987 . Also, positive volatility leads the Atkinson index from 1917 to 1964 and from 2004 to 2015.

With negative volatility at high frequencies, the results show that all the inequality measures lead negative volatility from 1994 to 2015, whereas negative volatility leads all the inequality measures except Top 10\% and Top 5\% from 1917 to 1940 . In the 1940 s, the direction of causality changes from negative volatility leads to inequality leads, which relates to wage compression during the 1940s. Negative volatility leads Top $0.01 \%$ in $1917-1974$ and Top $0.01 \%$ leads negative volatility from 1975 . For wealth inequality, Top 1\% (p99p100) leads negative volatility from 1962 through 2014. The direction of causality of Top 10\% and Bottom 50\% change mid and late 1980s.

We observe that the directions of causality vary and the changes of direction mostly coincide with the business cycle (NBER). This probably relates to business cycle movements that associate with large permanent effects on the long-run level of output (Nelson and Plosser 1982; Campbell and Mankiw 1987). 
The results show that volatility, including positive and negative volatilities, mostly leads income inequality until the 2000s across low frequencies and changes direction from volatility leads to income inequality leads from the 2000 s onward. In contrast to the short term, long-term causality patterns and directions are robust to different measures of income inequality. Across high frequencies, the income share inequality measures lead volatilities, but directions of causality vary across frequencies and evolve with time. If we restrict our analysis to classical time series, we cannot find any information about differences across frequencies.

\section{Conclusion}

Policy makers attempt to reduce inequality through economic growth, fiscal policy, monetary policy, aid programs, and so on. The relationship between inequality and the various policy instruments receives much discussion and analysis in the existing literature. As numerous variables affect each other simultaneously or at different points of time, rendering net causality and correlation results difficult to document. This paper investigates the causal relationships between U.S. income and wealth inequality measures, and output volatility. We use wavelet analysis, which allows the causal relationship between the two series to vary over time and frequency. Wavelet analysis is robust to lag length, stationarity, cointegration, and model specification. Furthermore, it permits the consideration of cointegration and causality. We use annual time-series data from 1917 to 2015 for volatility and income inequality and 1962 to 2014 for volatility and wealth inequality, which cover numerous economic expansions and contraction.

Our results show that the periods and directions of short-term causality vary over time. Volatility mainly leads income inequality measures over the long-run through the early-2000s. At high frequencies, causality changes direction - from volatility leading to inequality leading. Our results also show that higher positive and negative volatility leads to increases in inequality. This implies that economic growth does not trickle down to the bottom income 
group as they experience more fluctuations in output growth. In addition, we find that volatility not only matters for inequality but also inequality matters for volatility, especially in more recent years.

As our long-term results show, changes in the direction of causality from volatility leads to income inequality leads coincides with the end of the Great moderation era. Policy makers can use direct policy, such as enlarging the tax bracket for low-income households, raising taxes on high-income households, or increasing state aid programs, to reduce inequality, which can also moderate volatility. Our findings also imply that stabilization policies can affect income inequality. Thus, stabilization policy can provide an important instrument to reduce income inequality. This finding corresponds with studies ${ }^{8}$ that find a significant effect from aid programs and/or remittances on inequality via stabilizing effects on volatility.

To fully understand the effects of volatility on inequality, we need a detailed examination of all possible channels, as different mechanisms may require different policy implications. We leave this issue for future study.

\footnotetext{
${ }^{8}$ See Chauvet and Guillaumont 2001, 2009; Guillaumont and Wagner, 2014 for the related study
} 
Table 1. Wavelet phase difference (Volatility, logarithm of Atkinson Index)

\begin{tabular}{|c|c|c|c|c|}
\hline \multicolumn{5}{|c|}{ Volatility } \\
\hline $\begin{array}{l}\text { High } \\
\text { frequency }\end{array}$ & Period & Phase & $\begin{array}{c}\text { Sign of } \\
\text { co-movement }\end{array}$ & Causality \\
\hline & $1917-1958$ & $\left(\frac{-\pi}{2}, 0\right)$, In-phase & + & Volatility $\rightarrow$ Atkin 05 \\
\hline & $1959-2015$ & $\left(0, \frac{\pi}{2}\right)$, In-phase & + & Atkin $05 \rightarrow$ Volatility \\
\hline $\begin{array}{l}\text { Low } \\
\text { frequency }\end{array}$ & $1917-1997$ & $\left(\frac{-\pi}{2}, 0\right)$, In-phase & + & Volatility $\rightarrow$ Atkin 05 \\
\hline & $1998-2015$ & $\left(0, \frac{\pi}{2}\right)$, In-phase & + & Atkin $05 \rightarrow$ Volatility \\
\hline \multicolumn{5}{|c|}{ Good / (+) Volatility } \\
\hline \multirow[t]{4}{*}{$\begin{array}{l}\text { High } \\
\text { frequency }\end{array}$} & Period & Phase & $\begin{array}{c}\text { Sign of } \\
\text { co-movement }\end{array}$ & Causality \\
\hline & $1917-1964$ & $\left(\frac{-\pi}{2}, 0\right)$, In-phase & + & Volatility $\rightarrow$ Atkin 05 \\
\hline & $1965-2003$ & $\left(0, \frac{\pi}{2}\right)$, In-phase & + & Atkin $05 \rightarrow$ Volatility \\
\hline & $2004-2015$ & $\left(\frac{-\pi}{2}, 0\right)$, In-phase & + & Volatility $\rightarrow$ Atkin 05 \\
\hline \multirow[t]{2}{*}{$\begin{array}{l}\text { Low } \\
\text { frequency }\end{array}$} & $1917-1998$ & $\left(\frac{-\pi}{2}, 0\right)$, In-phase & + & Volatility $\rightarrow$ Atkin 05 \\
\hline & $1999-2015$ & $\left(0, \frac{\pi}{2}\right)$, In-phase & + & Atkin $05 \rightarrow$ Volatility \\
\hline \multicolumn{5}{|c|}{$\mathrm{Bad} /(-)$ Volatility } \\
\hline \multirow[t]{3}{*}{$\begin{array}{l}\text { High } \\
\text { frequency }\end{array}$} & Period & Phase & $\begin{array}{c}\text { Sign of } \\
\text { co-movement }\end{array}$ & Causality \\
\hline & $1917-1951$ & $\left(\frac{-\pi}{2}, 0\right)$, In-phase & + & Volatility $\rightarrow$ Atkin 05 \\
\hline & $1952-2015$ & $\left(0, \frac{\pi}{2}\right)$, In-phase & + & Atkin $05 \rightarrow$ Volatility \\
\hline $\begin{array}{l}\text { Low } \\
\text { frequency }\end{array}$ & $1917-2015$ & $\left(\frac{-\pi}{2}, 0\right)$, In-phase & + & Volatility $\rightarrow$ Atkin 05 \\
\hline
\end{tabular}


Table 2. Wavelet phase difference (Volatility, logarithm of Gini coefficient)

\begin{tabular}{|c|c|c|c|c|}
\hline \multicolumn{5}{|c|}{ Volatility } \\
\hline $\begin{array}{l}\text { High } \\
\text { frequency }\end{array}$ & Period & Phase & $\begin{array}{c}\text { Sign of } \\
\text { co-movement }\end{array}$ & Causality \\
\hline & $1917-1960$ & $\left(\frac{-\pi}{2}, 0\right)$, In-phase & + & $\begin{array}{l}\text { Volatility } \rightarrow \text { Gini } \\
\text { coefficient }\end{array}$ \\
\hline & $1961-1983$ & $\left(0, \frac{\pi}{2}\right)$, In-phase & + & Gini $\rightarrow$ Volatility \\
\hline & $1984-1985$ & $\left(\frac{-\pi}{2}, 0\right)$, In-phase & + & Volatility $\rightarrow$ Gini \\
\hline & 1986-1987 & $\left(0, \frac{\pi}{2}\right)$, In-phase & + & Gini $\rightarrow$ Volatility \\
\hline & $1988-2015$ & $\left(\frac{-\pi}{2}, 0\right)$, In-phase & + & Volatility $\rightarrow$ Gini \\
\hline $\begin{array}{l}\text { Low } \\
\text { frequency }\end{array}$ & $1917-2015$ & $\left(\frac{-\pi}{2}, 0\right)$, In-phase & + & Volatility $\rightarrow$ Gini \\
\hline \multicolumn{5}{|c|}{ Good / (+) Volatility } \\
\hline $\begin{array}{l}\text { High } \\
\text { frequency }\end{array}$ & Period & Phase & $\begin{array}{c}\text { Sign of } \\
\text { co-movement }\end{array}$ & Causality \\
\hline & $1917-1978$ & $\left(\frac{-\pi}{2}, 0\right)$, In-phase & + & Volatility $\rightarrow$ Gini \\
\hline & $1979-1987$ & $\left(0, \frac{\pi}{2}\right)$, In-phase & + & Gini $\rightarrow$ Volatility \\
\hline & $1988-2015$ & $\left(\frac{-\pi}{2}, 0\right)$, In-phase & + & Volatility $\rightarrow$ Gini \\
\hline $\begin{array}{l}\text { Low } \\
\text { frequency }\end{array}$ & $1917-2015$ & $\left(\frac{-\pi}{2}, 0\right)$, In-phase & + & Volatility $\rightarrow$ Gini \\
\hline \multicolumn{5}{|c|}{ Bad / (-) Volatility } \\
\hline $\begin{array}{l}\text { High } \\
\text { frequency }\end{array}$ & Period & Phase & $\begin{array}{c}\text { Sign of } \\
\text { co-movement }\end{array}$ & Causality \\
\hline & 1917-1946 & $\left(\frac{-\pi}{2}, 0\right)$, In-phase & + & Volatility $\rightarrow$ Gini \\
\hline & $1947-1976$ & $\left(0, \frac{\pi}{2}\right)$, In-phase & + & Gini $\rightarrow$ Volatility \\
\hline & $1977-1993$ & $\left(\frac{-\pi}{2}, 0\right)$, In-phase & + & Volatility $\rightarrow$ Gini \\
\hline & 1994-2015 & $\left(0, \frac{\pi}{2}\right)$, In-phase & + & Gini $\rightarrow$ Volatility \\
\hline $\begin{array}{l}\text { Low } \\
\text { frequency }\end{array}$ & $1917-2015$ & $\left(\frac{-\pi}{2}, 0\right)$, In-phase & + & Volatility $\rightarrow$ Gini \\
\hline
\end{tabular}


Table 3. Wavelet phase difference (Volatility, logarithm of the Relative Mean Deviation)

\begin{tabular}{|c|c|c|c|c|}
\hline \multicolumn{5}{|c|}{ Volatility } \\
\hline \multirow[t]{3}{*}{$\begin{array}{l}\text { High } \\
\text { frequency }\end{array}$} & Period & Phase & $\begin{array}{c}\text { Sign of } \\
\text { co-movement }\end{array}$ & Causality \\
\hline & $1917-1960$ & $\left(\frac{-\pi}{2}, 0\right)$, In-phase & + & Volatility $\rightarrow$ Rmeandev \\
\hline & $1961-2015$ & $\left(0, \frac{\pi}{2}\right)$, In-phase & + & Rmeandev $\rightarrow$ Volatility \\
\hline \multirow[t]{2}{*}{$\begin{array}{l}\text { Low } \\
\text { frequency }\end{array}$} & $1917-2012$ & $\left(\frac{-\pi}{2}, 0\right)$, In-phase & + & Volatility $\rightarrow$ Rmeandev \\
\hline & $2013-2015$ & $\left(0, \frac{\pi}{2}\right)$, In-phase & + & Rmeandev $\rightarrow$ Volatility \\
\hline \multicolumn{5}{|c|}{ Good / (+) Volatility } \\
\hline \multirow[t]{4}{*}{$\begin{array}{l}\text { High } \\
\text { frequency }\end{array}$} & Period & Phase & $\begin{array}{c}\text { Sign of } \\
\text { co-movement }\end{array}$ & Causality \\
\hline & $1917-1968$ & $\left(\frac{-\pi}{2}, 0\right)$, In-phase & + & Volatility $\rightarrow$ Rmeandev \\
\hline & 1969-1989 & $\left(0, \frac{\pi}{2}\right)$, In-phase & + & Rmeandev $\rightarrow$ Volatility \\
\hline & $1990-2015$ & $\left(\frac{-\pi}{2}, 0\right)$, In-phase & + & Volatility $\rightarrow$ Rmeandev \\
\hline \multirow[t]{2}{*}{$\begin{array}{l}\text { Low } \\
\text { frequency }\end{array}$} & $1917-2014$ & $\left(\frac{-\pi}{2}, 0\right)$, In-phase & + & Volatility $\rightarrow$ Rmeandev \\
\hline & 2015 & $\left(0, \frac{\pi}{2}\right)$, In-phase & + & Rmeandev $\rightarrow$ Volatility \\
\hline \multicolumn{5}{|c|}{ Bad / (-) Volatility } \\
\hline \multirow[t]{5}{*}{$\begin{array}{l}\text { High } \\
\text { frequency }\end{array}$} & Period & Phase & $\begin{array}{c}\text { Sign of } \\
\text { co-movement }\end{array}$ & Causality \\
\hline & $1917-1945$ & $\left(\frac{-\pi}{2}, 0\right)$, In-phase & + & Volatility $\rightarrow$ Rmeandev \\
\hline & 1946-1979 & $\left(0, \frac{\pi}{2}\right)$, In-phase & + & Rmeandev $\rightarrow$ Volatility \\
\hline & $1980-1990$ & $\left(\frac{-\pi}{2}, 0\right)$, In-phase & + & Volatility $\rightarrow$ Rmeandev \\
\hline & $1991-2015$ & $\left(0, \frac{\pi}{2}\right)$, In-phase & + & Rmeandev $\rightarrow$ Volatility \\
\hline $\begin{array}{l}\text { Low } \\
\text { frequency }\end{array}$ & $1917-2015$ & $\left(\frac{-\pi}{2}, 0\right)$, In-phase & + & Volatility $\rightarrow$ Rmeandev \\
\hline
\end{tabular}


Table 4. Wavelet phase difference (Volatility, logarithm of Theil Index)

\begin{tabular}{|c|c|c|c|c|}
\hline \multicolumn{5}{|c|}{ Volatility } \\
\hline $\begin{array}{l}\text { High } \\
\text { frequency }\end{array}$ & Period & Phase & $\begin{array}{c}\text { Sign of } \\
\text { co-movement }\end{array}$ & Causality \\
\hline & $1917-1954$ & $\left(\frac{-\pi}{2}, 0\right)$, In-phase & + & Volatility $\rightarrow$ Theil \\
\hline & $1955-1988$ & $\left(0, \frac{\pi}{2}\right)$, In-phase & + & Theil $\rightarrow$ Volatility \\
\hline & $1989-2015$ & $\left(\frac{-\pi}{2}, 0\right)$, In-phase & + & Volatility $\rightarrow$ Theil \\
\hline $\begin{array}{l}\text { Low } \\
\text { frequency }\end{array}$ & $1917-2012$ & $\left(\frac{-\pi}{2}, 0\right)$, In-phase & + & Volatility $\rightarrow$ Theil \\
\hline & $2013-2015$ & $\left(0, \frac{\pi}{2}\right)$, In-phase & + & Theil $\rightarrow$ Volatility \\
\hline \multicolumn{5}{|c|}{ Good / $(+)$ Volatility } \\
\hline \multirow[t]{4}{*}{$\begin{array}{l}\text { High } \\
\text { frequency }\end{array}$} & Period & Phase & $\begin{array}{c}\text { Sign of } \\
\text { co-movement }\end{array}$ & Causality \\
\hline & $1917-1961$ & $\left(\frac{-\pi}{2}, 0\right)$, In-phase & + & Volatility $\rightarrow$ Theil \\
\hline & $1962-1986$ & $\left(0, \frac{\pi}{2}\right)$, In-phase & + & Theil $\rightarrow$ Volatility \\
\hline & $1987-2015$ & $\left(\frac{-\pi}{2}, 0\right)$, In-phase & + & Volatility $\rightarrow$ Theil \\
\hline \multirow[t]{2}{*}{$\begin{array}{l}\text { Low } \\
\text { frequency }\end{array}$} & $1917-2007$ & $\left(\frac{-\pi}{2}, 0\right)$, In-phase & + & Volatility $\rightarrow$ Theil \\
\hline & $2008-2015$ & $\left(0, \frac{\pi}{2}\right)$, In-phase & + & Theil $\rightarrow$ Volatility \\
\hline \multicolumn{5}{|c|}{ Bad / (-) Volatility } \\
\hline \multirow[t]{5}{*}{$\begin{array}{l}\text { High } \\
\text { frequency }\end{array}$} & Period & Phase & $\begin{array}{c}\text { Sign of } \\
\text { co-movement }\end{array}$ & Causality \\
\hline & $1917-1951$ & $\left(\frac{-\pi}{2}, 0\right)$, In-phase & + & Volatility $\rightarrow$ Theil \\
\hline & $1952-1978$ & $\left(0, \frac{\pi}{2}\right)$, In-phase & + & Theil $\rightarrow$ Volatility \\
\hline & 1979-1992 & $\left(\frac{-\pi}{2}, 0\right)$, In-phase & + & Volatility $\rightarrow$ Theil \\
\hline & $1993-2015$ & $\left(0, \frac{\pi}{2}\right)$, In-phase & + & Theil $\rightarrow$ Volatility \\
\hline $\begin{array}{l}\text { Low } \\
\text { frequency }\end{array}$ & $1917-2015$ & $\left(\frac{-\pi}{2}, 0\right)$, In-phase & + & Volatility $\rightarrow$ Theil \\
\hline
\end{tabular}


Table 5. Wavelet phase difference (Volatility, logarithm of Top 10\%)

\begin{tabular}{|c|c|c|c|c|}
\hline \multicolumn{5}{|c|}{ Volatility } \\
\hline $\begin{array}{l}\text { High } \\
\text { frequency }\end{array}$ & Period & Phase & $\begin{array}{c}\text { Sign of } \\
\text { co-movement }\end{array}$ & Causality \\
\hline & $1917-2015$ & $\left(0, \frac{\pi}{2}\right)$, In-phase & + & Top $10 \% \rightarrow$ Volatility \\
\hline $\begin{array}{l}\text { Low } \\
\text { frequency }\end{array}$ & $1917-2008$ & $\left(\frac{-\pi}{2}, 0\right)$, In-phase & + & Volatility $\rightarrow$ Top $10 \%$ \\
\hline & $2009-2015$ & $\left(0, \frac{\pi}{2}\right)$, In-phase & + & Top $10 \% \rightarrow$ Volatility \\
\hline \multicolumn{5}{|c|}{ Good / (+) Volatility } \\
\hline \multirow[t]{5}{*}{$\begin{array}{l}\text { High } \\
\text { frequency }\end{array}$} & Period & Phase & $\begin{array}{c}\text { Sign of } \\
\text { co-movement }\end{array}$ & Causality \\
\hline & $1917-1931$ & $\left(0, \frac{\pi}{2}\right)$, In-phase & + & Top $10 \% \rightarrow$ Volatility \\
\hline & $1932-1963$ & $\left(\frac{-\pi}{2}, 0\right)$, In-phase & + & Volatility $\rightarrow$ Top $10 \%$ \\
\hline & 1964-2006 & $\left(0, \frac{\pi}{2}\right)$, In-phase & + & Top $10 \% \rightarrow$ Volatility \\
\hline & $2007-2015$ & $\left(\frac{-\pi}{2}, 0\right)$, In-phase & + & Volatility $\rightarrow$ Top $10 \%$ \\
\hline \multirow[t]{2}{*}{$\begin{array}{l}\text { Low } \\
\text { frequency }\end{array}$} & $1917-2007$ & $\left(\frac{-\pi}{2}, 0\right)$, In-phase & + & Volatility $\rightarrow$ Top $10 \%$ \\
\hline & $2008-2015$ & $\left(0, \frac{\pi}{2}\right)$, In-phase & + & Top $10 \% \rightarrow$ Volatility \\
\hline \multicolumn{5}{|c|}{ Bad / (-) Volatility } \\
\hline \multirow[t]{2}{*}{$\begin{array}{l}\text { High } \\
\text { frequency }\end{array}$} & Period & Phase & $\begin{array}{c}\text { Sign of } \\
\text { co-movement }\end{array}$ & Causality \\
\hline & $1917-2015$ & $\left(0, \frac{\pi}{2}\right)$, In-phase & + & Top $10 \% \rightarrow$ Volatility \\
\hline \multirow[t]{2}{*}{$\begin{array}{l}\text { Low } \\
\text { frequency }\end{array}$} & $1917-2005$ & $\left(\frac{-\pi}{2}, 0\right)$, In-phase & + & Volatility $\rightarrow$ Top $10 \%$ \\
\hline & $2006-2015$ & $\left(0, \frac{\pi}{2}\right)$, In-phase & + & Top $10 \% \rightarrow$ Volatility \\
\hline
\end{tabular}


Table 6. Wavelet phase difference (Volatility, logarithm of Top 5\%)

\begin{tabular}{|c|c|c|c|c|}
\hline \multicolumn{5}{|c|}{ Volatility } \\
\hline $\begin{array}{l}\text { High } \\
\text { frequency }\end{array}$ & Period & Phase & $\begin{array}{c}\text { Sign of } \\
\text { co-movement }\end{array}$ & Causality \\
\hline & $1917-1918$ & $\left(\frac{-\pi}{2}, 0\right)$, In-phase & + & Volatility $\rightarrow$ Top 5\% \\
\hline & 1919 & $\left(0, \frac{\pi}{2}\right)$, In-phase & + & Top $5 \% \rightarrow$ Volatility \\
\hline & $1920-1921$ & $\left(\frac{-\pi}{2}, 0\right)$, In-phase & + & Volatility $\rightarrow$ Top $5 \%$ \\
\hline & $1922-2015$ & $\left(0, \frac{\pi}{2}\right)$, In-phase & + & Top $5 \% \rightarrow$ Volatility \\
\hline $\begin{array}{l}\text { Low } \\
\text { frequency }\end{array}$ & $1917-2003$ & $\left(\frac{-\pi}{2}, 0\right)$, In-phase & + & Volatility $\rightarrow$ Top 5\% \\
\hline & $2004-2015$ & $\left(0, \frac{\pi}{2}\right)$, In-phase & + & Top $5 \% \rightarrow$ Volatility \\
\hline \multicolumn{5}{|c|}{ Good / $(+)$ Volatility } \\
\hline $\begin{array}{l}\text { High } \\
\text { frequency }\end{array}$ & Period & Phase & $\begin{array}{c}\text { Sign of } \\
\text { co-movement }\end{array}$ & Causality \\
\hline & $1917-1926$ & $\left(0, \frac{\pi}{2}\right)$, In-phase & + & Top $5 \% \rightarrow$ Volatility \\
\hline & $1927-1959$ & $\left(\frac{-\pi}{2}, 0\right)$, In-phase & + & Volatility $\rightarrow$ Top 5\% \\
\hline & $1960-2009$ & $\left(0, \frac{\pi}{2}\right)$, In-phase & + & Top $5 \% \rightarrow$ Volatility \\
\hline & $2010-2015$ & $\left(\frac{-\pi}{2}, 0\right)$, In-phase & + & Volatility $\rightarrow$ Top $5 \%$ \\
\hline $\begin{array}{l}\text { Low } \\
\text { frequency }\end{array}$ & $1917-2004$ & $\left(\frac{-\pi}{2}, 0\right)$, In-phase & + & Volatility $\rightarrow$ Top 5\% \\
\hline & $2005-2015$ & $\left(0, \frac{\pi}{2}\right)$, In-phase & + & Top $5 \% \rightarrow$ Volatility \\
\hline \multicolumn{5}{|c|}{ Bad / (-) Volatility } \\
\hline $\begin{array}{l}\text { High } \\
\text { frequency }\end{array}$ & Period & Phase & $\begin{array}{c}\text { Sign of } \\
\text { co-movement }\end{array}$ & Causality \\
\hline & $1917-1927$ & $\left(\frac{-\pi}{2}, 0\right)$, In-phase & + & Volatility $\rightarrow$ Top $5 \%$ \\
\hline & $1928-2015$ & $\left(0, \frac{\pi}{2}\right)$, In-phase & + & Top $5 \% \rightarrow$ Volatility \\
\hline $\begin{array}{l}\text { Low } \\
\text { frequency }\end{array}$ & $1917-2000$ & $\left(\frac{-\pi}{2}, 0\right)$, In-phase & + & Volatility $\rightarrow$ Top 5\% \\
\hline & $2001-2015$ & $\left(0, \frac{\pi}{2}\right)$, In-phase & + & Top $5 \% \rightarrow$ Volatility \\
\hline
\end{tabular}


Table 7. Wavelet phase difference (Volatility, logarithm of Top 1\%)

\begin{tabular}{|c|c|c|c|c|}
\hline \multicolumn{5}{|c|}{ Volatility } \\
\hline $\begin{array}{l}\text { High } \\
\text { frequency }\end{array}$ & Period & Phase & $\begin{array}{c}\text { Sign of } \\
\text { co-movement }\end{array}$ & Causality \\
\hline & $1917-2015$ & $\left(0, \frac{\pi}{2}\right)$, In-phase & + & Top $1 \% \rightarrow$ Volatility \\
\hline $\begin{array}{l}\text { Low } \\
\text { frequency }\end{array}$ & $1917-2001$ & $\left(\frac{-\pi}{2}, 0\right)$, In-phase & + & Volatility $\rightarrow$ Top $1 \%$ \\
\hline & $2002-2015$ & $\left(0, \frac{\pi}{2}\right)$, In-phase & + & Top $1 \% \rightarrow$ Volatility \\
\hline \multicolumn{5}{|c|}{ Good / (+) Volatility } \\
\hline \multirow[t]{3}{*}{$\begin{array}{l}\text { High } \\
\text { frequency }\end{array}$} & Period & Phase & $\begin{array}{c}\text { Sign of } \\
\text { co-movement }\end{array}$ & Causality \\
\hline & $1917-2012$ & $\left(0, \frac{\pi}{2}\right)$, In-phase & + & Top $1 \% \rightarrow$ Volatility \\
\hline & $2013-2015$ & $\left(\frac{-\pi}{2}, 0\right)$, In-phase & + & Volatility $\rightarrow$ Top $1 \%$ \\
\hline \multirow[t]{2}{*}{$\begin{array}{l}\text { Low } \\
\text { frequency }\end{array}$} & $1917-2001$ & $\left(\frac{-\pi}{2}, 0\right)$, In-phase & + & Volatility $\rightarrow$ Top $1 \%$ \\
\hline & $2002-2015$ & $\left(0, \frac{\pi}{2}\right)$, In-phase & + & Top $1 \% \rightarrow$ Volatility \\
\hline \multicolumn{5}{|c|}{ Bad / (-) Volatility } \\
\hline \multirow[t]{7}{*}{$\begin{array}{l}\text { High } \\
\text { frequency }\end{array}$} & Period & Phase & $\begin{array}{c}\text { Sign of } \\
\text { co-movement }\end{array}$ & Causality \\
\hline & $1917-1940$ & $\left(\frac{-\pi}{2}, 0\right)$, In-phase & + & Volatility $\rightarrow$ Top $1 \%$ \\
\hline & $1941-1960$ & $\left(0, \frac{\pi}{2}\right)$, In-phase & + & Top $1 \% \rightarrow$ Volatility \\
\hline & $1961-1970$ & $\left(\frac{-\pi}{2}, 0\right)$, In-phase & + & Volatility $\rightarrow$ Top $1 \%$ \\
\hline & $1971-1972$ & $\left(0, \frac{\pi}{2}\right)$, In-phase & + & Top $1 \% \rightarrow$ Volatility \\
\hline & 1973 & $\left(\frac{-\pi}{2}, 0\right)$, In-phase & + & Volatility $\rightarrow$ Top $1 \%$ \\
\hline & $1974-2015$ & $\left(0, \frac{\pi}{2}\right)$, In-phase & + & Top $1 \% \rightarrow$ Volatility \\
\hline \multirow[t]{2}{*}{$\begin{array}{l}\text { Low } \\
\text { frequency }\end{array}$} & $1917-2002$ & $\left(\frac{-\pi}{2}, 0\right)$, In-phase & + & Volatility $\rightarrow$ Top $1 \%$ \\
\hline & $2003-2015$ & $\left(0, \frac{\pi}{2}\right)$, In-phase & + & Top $1 \% \rightarrow$ Volatility \\
\hline
\end{tabular}


Table 8. Wavelet phase difference (Volatility, logarithm of Top $0.5 \%$ )

\begin{tabular}{|c|c|c|c|c|}
\hline \multicolumn{5}{|c|}{ Volatility } \\
\hline $\begin{array}{l}\text { High } \\
\text { frequency }\end{array}$ & Period & Phase & $\begin{array}{c}\text { Sign of } \\
\text { co-movement }\end{array}$ & Causality \\
\hline & $1917-2015$ & $\left(0, \frac{\pi}{2}\right)$, In-phase & + & Top $0.5 \% \rightarrow$ Volatility \\
\hline $\begin{array}{l}\text { Low } \\
\text { frequency }\end{array}$ & $1917-2004$ & $\left(\frac{-\pi}{2}, 0\right)$, In-phase & + & Volatility $\rightarrow$ Top $0.5 \%$ \\
\hline & 2005-2015 & $\left(0, \frac{\pi}{2}\right)$, In-phase & + & Top $0.5 \% \rightarrow$ Volatility \\
\hline \multicolumn{5}{|c|}{ Good / (+) Volatility } \\
\hline \multirow[t]{3}{*}{$\begin{array}{l}\text { High } \\
\text { frequency }\end{array}$} & Period & Phase & $\begin{array}{c}\text { Sign of } \\
\text { co-movement }\end{array}$ & Causality \\
\hline & $1917-2014$ & $\left(0, \frac{\pi}{2}\right)$, In-phase & + & Top $0.5 \% \rightarrow$ Volatility \\
\hline & 2015 & $\left(\frac{-\pi}{2}, 0\right)$, In-phase & + & Volatility $\rightarrow$ Top $0.5 \%$ \\
\hline \multirow[t]{2}{*}{$\begin{array}{l}\text { Low } \\
\text { frequency }\end{array}$} & $1917-2004$ & $\left(\frac{-\pi}{2}, 0\right)$, In-phase & + & Volatility $\rightarrow$ Top $0.5 \%$ \\
\hline & 2005-2015 & $\left(0, \frac{\pi}{2}\right)$, In-phase & + & Top $0.5 \% \rightarrow$ Volatility \\
\hline \multicolumn{5}{|c|}{ Bad / (-) Volatility } \\
\hline \multirow[t]{5}{*}{$\begin{array}{l}\text { High } \\
\text { frequency }\end{array}$} & Period & Phase & $\begin{array}{c}\text { Sign of } \\
\text { co-movement }\end{array}$ & Causality \\
\hline & $1917-1943$ & $\left(\frac{-\pi}{2}, 0\right)$, In-phase & + & Volatility $\rightarrow$ Top $0.5 \%$ \\
\hline & 1944-1957 & $\left(0, \frac{\pi}{2}\right)$, In-phase & + & Top $0.5 \% \rightarrow$ Volatility \\
\hline & $1958-1964$ & $\left(\frac{-\pi}{2}, 0\right)$, In-phase & + & Volatility $\rightarrow$ Top $0.5 \%$ \\
\hline & $1965-2015$ & $\left(0, \frac{\pi}{2}\right)$, In-phase & + & Top $0.5 \% \rightarrow$ Volatility \\
\hline $\begin{array}{l}\text { Low } \\
\text { frequency }\end{array}$ & $1917-2004$ & $\left(\frac{-\pi}{2}, 0\right)$, In-phase & + & Volatility $\rightarrow$ Top $0.5 \%$ \\
\hline & $2005-2015$ & $\left(0, \frac{\pi}{2}\right)$, In-phase & + & Top $0.5 \% \rightarrow$ Volatility \\
\hline
\end{tabular}


Table 9. Wavelet phase difference (Volatility, logarithm of Top $0.1 \%$ )

\begin{tabular}{|c|c|c|c|c|}
\hline \multicolumn{5}{|c|}{ Volatility } \\
\hline $\begin{array}{l}\text { High } \\
\text { frequency }\end{array}$ & Period & Phase & $\begin{array}{c}\text { Sign of } \\
\text { co-movement }\end{array}$ & Causality \\
\hline & $1917-1938$ & $\left(\frac{-\pi}{2}, 0\right)$, In-phase & + & Volatility $\rightarrow$ Top $0.1 \%$ \\
\hline & $1939-2015$ & $\left(0, \frac{\pi}{2}\right)$, In-phase & + & Top $0.1 \% \rightarrow$ Volatility \\
\hline $\begin{array}{l}\text { Low } \\
\text { frequency }\end{array}$ & $1917-2004$ & $\left(\frac{-\pi}{2}, 0\right)$, In-phase & + & Volatility $\rightarrow$ Top $0.1 \%$ \\
\hline & $2005-2015$ & $\left(0, \frac{\pi}{2}\right)$, In-phase & + & Top $0.1 \% \rightarrow$ Volatility \\
\hline \multicolumn{5}{|c|}{ Good / (+) Volatility } \\
\hline \multirow[t]{2}{*}{$\begin{array}{l}\text { High } \\
\text { frequency }\end{array}$} & Period & Phase & $\begin{array}{c}\text { Sign of } \\
\text { co-movement }\end{array}$ & Causality \\
\hline & $1917-2015$ & $\left(0, \frac{\pi}{2}\right)$, In-phase & + & Top $0.1 \% \rightarrow$ Volatility \\
\hline \multirow[t]{2}{*}{$\begin{array}{l}\text { Low } \\
\text { frequency }\end{array}$} & $1917-2004$ & $\left(\frac{-\pi}{2}, 0\right)$, In-phase & + & Volatility $\rightarrow$ Top $0.1 \%$ \\
\hline & $2005-2015$ & $\left(0, \frac{\pi}{2}\right)$, In-phase & + & Top $0.1 \% \rightarrow$ Volatility \\
\hline \multicolumn{5}{|c|}{ Bad / (-) Volatility } \\
\hline \multirow[t]{9}{*}{$\begin{array}{l}\text { High } \\
\text { frequency }\end{array}$} & Period & Phase & $\begin{array}{c}\text { Sign of } \\
\text { co-movement }\end{array}$ & Causality \\
\hline & $1917-1946$ & $\left(\frac{-\pi}{2}, 0\right)$, In-phase & + & Volatility $\rightarrow$ Top $0.1 \%$ \\
\hline & $1947-1952$ & $\left(0, \frac{\pi}{2}\right)$, In-phase & + & Top $0.1 \% \rightarrow$ Volatility \\
\hline & $1953-1954$ & $\left(\frac{-\pi}{2}, 0\right)$, In-phase & + & Volatility $\rightarrow$ Top $0.1 \%$ \\
\hline & 1955 & $\left(0, \frac{\pi}{2}\right)$, In-phase & + & Top $0.1 \% \rightarrow$ Volatility \\
\hline & $1956-1957$ & $\left(\frac{-\pi}{2}, 0\right)$, In-phase & + & Volatility $\rightarrow$ Top $0.1 \%$ \\
\hline & 1958 & $\left(0, \frac{\pi}{2}\right)$, In-phase & + & Top $0.1 \% \rightarrow$ Volatility \\
\hline & $1959-1972$ & $\left(\frac{-\pi}{2}, 0\right)$, In-phase & + & Volatility $\rightarrow$ Top $0.1 \%$ \\
\hline & $1973-2015$ & $\left(0, \frac{\pi}{2}\right)$, In-phase & + & Top $0.1 \% \rightarrow$ Volatility \\
\hline $\begin{array}{l}\text { Low } \\
\text { frequency }\end{array}$ & $1917-2007$ & $\left(\frac{-\pi}{2}, 0\right)$, In-phase & + & Volatility $\rightarrow$ Top $0.1 \%$ \\
\hline & $2008-2015$ & $\left(0, \frac{\pi}{2}\right)$, In-phase & + & Top $0.1 \% \rightarrow$ Volatility \\
\hline
\end{tabular}


Table 10. Wavelet phase difference (Volatility, logarithm of Top $0.01 \%$ )

\begin{tabular}{|c|c|c|c|c|}
\hline \multicolumn{5}{|c|}{ Volatility } \\
\hline $\begin{array}{l}\text { High } \\
\text { frequency }\end{array}$ & Period & Phase & $\begin{array}{c}\text { Sign of } \\
\text { co-movement }\end{array}$ & Causality \\
\hline & $1917-1943$ & $\left(\frac{-\pi}{2}, 0\right)$, In-phase & + & Volatility $\rightarrow$ Top $0.01 \%$ \\
\hline & $1944-2015$ & $\left(0, \frac{\pi}{2}\right)$, In-phase & + & Top $0.01 \% \rightarrow$ Volatility \\
\hline $\begin{array}{l}\text { Low } \\
\text { frequency }\end{array}$ & $1917-2008$ & $\left(\frac{-\pi}{2}, 0\right)$, In-phase & + & Volatility $\rightarrow$ Top $0.01 \%$ \\
\hline & $2009-2015$ & $\left(0, \frac{\pi}{2}\right)$, In-phase & + & Top $0.01 \% \rightarrow$ Volatility \\
\hline \multicolumn{5}{|c|}{ Good / (+) Volatility } \\
\hline \multirow[t]{3}{*}{$\begin{array}{l}\text { High } \\
\text { frequency }\end{array}$} & Period & Phase & $\begin{array}{c}\text { Sign of } \\
\text { co-movement }\end{array}$ & Causality \\
\hline & $1917-1929$ & $\left(\frac{-\pi}{2}, 0\right)$, In-phase & + & Volatility $\rightarrow$ Top $0.01 \%$ \\
\hline & $1930-2015$ & $\left(0, \frac{\pi}{2}\right)$, In-phase & + & Top $0.01 \% \rightarrow$ Volatility \\
\hline \multirow[t]{2}{*}{$\begin{array}{l}\text { Low } \\
\text { frequency }\end{array}$} & $1917-2005$ & $\left(\frac{-\pi}{2}, 0\right)$, In-phase & + & Volatility $\rightarrow$ Top $0.01 \%$ \\
\hline & 2006-2015 & $\left(0, \frac{\pi}{2}\right)$, In-phase & + & Top $0.01 \% \rightarrow$ Volatility \\
\hline \multicolumn{5}{|c|}{$\mathrm{Bad} /(-)$ Volatility } \\
\hline \multirow[t]{3}{*}{$\begin{array}{l}\text { High } \\
\text { frequency }\end{array}$} & Period & Phase & $\begin{array}{c}\text { Sign of } \\
\text { co-movement }\end{array}$ & Causality \\
\hline & $1917-1974$ & $\left(\frac{-\pi}{2}, 0\right)$, In-phase & + & Volatility $\rightarrow$ Top $0.01 \%$ \\
\hline & $1975-2015$ & $\left(0, \frac{\pi}{2}\right)$, In-phase & + & Top $0.01 \% \rightarrow$ Volatility \\
\hline $\begin{array}{l}\text { Low } \\
\text { frequency }\end{array}$ & $1917-2015$ & $\left(\frac{-\pi}{2}, 0\right)$, In-phase & + & Volatility $\rightarrow$ Top $0.01 \%$ \\
\hline
\end{tabular}


Table 11. Wavelet phase difference (Volatility, Net personal wealth held by p90p100)

\begin{tabular}{|c|c|c|c|c|}
\hline \multicolumn{5}{|c|}{ Volatility } \\
\hline $\begin{array}{l}\text { High } \\
\text { frequency }\end{array}$ & Period & Phase & $\begin{array}{c}\text { Sign of } \\
\text { co-movement }\end{array}$ & Causality \\
\hline & $1962-1975$ & $\left(0, \frac{\pi}{2}\right)$, In-phase & + & p90p100 $\rightarrow$ Volatility \\
\hline & $1976-2014$ & $\left(\frac{-\pi}{2}, 0\right)$, In-phase & + & Volatility $\rightarrow$ p90p100 \\
\hline $\begin{array}{l}\text { Low } \\
\text { frequency }\end{array}$ & $1962-2014$ & $\left(\frac{-\pi}{2}, 0\right)$, In-phase & + & Volatility $\rightarrow$ p90p100 \\
\hline \multicolumn{5}{|c|}{ Good / (+) Volatility } \\
\hline \multirow[t]{3}{*}{$\begin{array}{l}\text { High } \\
\text { frequency }\end{array}$} & Period & Phase & $\begin{array}{c}\text { Sign of } \\
\text { co-movement }\end{array}$ & Causality \\
\hline & $1962-1976$ & $\left(0, \frac{\pi}{2}\right)$, In-phase & + & p90p100 $\rightarrow$ Volatility \\
\hline & $1977-2014$ & $\left(\frac{-\pi}{2}, 0\right)$, In-phase & + & Volatility $\rightarrow$ p90p100 \\
\hline \multirow[t]{2}{*}{$\begin{array}{l}\text { Low } \\
\text { frequency }\end{array}$} & $1962-2001$ & $\left(\frac{-\pi}{2}, 0\right)$, In-phase & + & Volatility $\rightarrow$ p90p100 \\
\hline & $2002-2014$ & $\left(0, \frac{\pi}{2}\right)$, In-phase & + & p90p100 $\rightarrow$ Volatility \\
\hline \multicolumn{5}{|c|}{ Bad / (-) Volatility } \\
\hline \multirow[t]{3}{*}{$\begin{array}{l}\text { High } \\
\text { frequency }\end{array}$} & Period & Phase & $\begin{array}{c}\text { Sign of } \\
\text { co-movement }\end{array}$ & Causality \\
\hline & $1962-1985$ & $\left(\frac{-\pi}{2}, 0\right)$, In-phase & + & Volatility $\rightarrow$ p90p100 \\
\hline & $1986-2014$ & $\left(0, \frac{\pi}{2}\right)$, In-phase & + & p90p100 $\rightarrow$ Volatility \\
\hline $\begin{array}{l}\text { Low } \\
\text { frequency }\end{array}$ & $1962-2014$ & $\left(\frac{-\pi}{2}, 0\right)$, In-phase & + & Volatility $\rightarrow$ p90p100 \\
\hline
\end{tabular}


Table 12. Wavelet phase difference (Volatility, Net personal wealth held by p50p90)

\begin{tabular}{|c|c|c|c|c|}
\hline \multicolumn{5}{|c|}{ Volatility } \\
\hline $\begin{array}{l}\text { High } \\
\text { frequency }\end{array}$ & Period & Phase & $\begin{array}{c}\text { Sign of } \\
\text { co-movement }\end{array}$ & Causality \\
\hline & $1962-1978$ & $\left(\frac{-\pi}{2}, 0\right)$, In-phase & + & Volatility $\rightarrow$ p50p90 \\
\hline & $1979-2014$ & $\left(0, \frac{\pi}{2}\right)$, In-phase & + & p50p90 $\rightarrow$ Volatility \\
\hline $\begin{array}{l}\text { Low } \\
\text { frequency }\end{array}$ & $1962-2014$ & $\left(\frac{-\pi}{2}, 0\right)$, In-phase & + & Volatility $\rightarrow$ p50p90 \\
\hline \multicolumn{5}{|c|}{ Good / $(+)$ Volatility } \\
\hline \multirow[t]{3}{*}{$\begin{array}{l}\text { High } \\
\text { frequency }\end{array}$} & Period & Phase & $\begin{array}{c}\text { Sign of } \\
\text { co-movement }\end{array}$ & Causality \\
\hline & $1692-1978$ & $\left(\frac{-\pi}{2}, 0\right)$, In-phase & + & Volatility $\rightarrow$ p50p90 \\
\hline & 1979-2014 & $\left(0, \frac{\pi}{2}\right)$, In-phase & + & p50p90 $\rightarrow$ Volatility \\
\hline \multirow[t]{2}{*}{$\begin{array}{l}\text { Low } \\
\text { frequency }\end{array}$} & $1962-1998$ & $\left(0, \frac{\pi}{2}\right)$, In-phase & + & p50p90 $\rightarrow$ Volatility \\
\hline & $1999-2014$ & $\left(\frac{-\pi}{2}, 0\right)$, In-phase & + & Volatility $\rightarrow$ p50p90 \\
\hline \multicolumn{5}{|c|}{ Bad / (-) Volatility } \\
\hline \multirow[t]{8}{*}{$\begin{array}{l}\text { High } \\
\text { frequency }\end{array}$} & Period & Phase & $\begin{array}{c}\text { Sign of } \\
\text { co-movement }\end{array}$ & Causality \\
\hline & $1962-1964$ & $\left(\frac{-\pi}{2}, 0\right)$, In-phase & + & Volatility $\rightarrow$ p50p90 \\
\hline & $1965-1967$ & $\left(0, \frac{\pi}{2}\right)$, In-phase & + & p50p90 $\rightarrow$ Volatility \\
\hline & $1968-1972$ & $\left(\frac{-\pi}{2}, 0\right)$, In-phase & + & Volatility $\rightarrow$ p50p90 \\
\hline & 1973-1979 & $\left(0, \frac{\pi}{2}\right)$, In-phase & + & p50p90 $\rightarrow$ Volatility \\
\hline & 1980-1981 & $\left(\frac{-\pi}{2}, 0\right)$, In-phase & + & Volatility $\rightarrow$ p50p90 \\
\hline & $1982-1983$ & $\left(0, \frac{\pi}{2}\right)$, In-phase & + & p50p90 $\rightarrow$ Volatility \\
\hline & 1984-2014 & $\left(\frac{-\pi}{2}, 0\right)$, In-phase & + & Volatility $\rightarrow$ p50p90 \\
\hline $\begin{array}{l}\text { Low } \\
\text { frequency }\end{array}$ & $1962-2014$ & $\left(0, \frac{\pi}{2}\right)$, In-phase & + & p50p90 $\rightarrow$ Volatility \\
\hline
\end{tabular}


Table 13. Wavelet phase difference (Volatility, Net personal wealth held by p0p50)

\begin{tabular}{|c|c|c|c|c|}
\hline \multicolumn{5}{|c|}{ Volatility } \\
\hline $\begin{array}{l}\text { High } \\
\text { frequency }\end{array}$ & Period & Phase & $\begin{array}{c}\text { Sign of } \\
\text { co-movement }\end{array}$ & Causality \\
\hline & $1962-2006$ & $\left(0, \frac{\pi}{2}\right)$, In-phase & + & p0p50 $\rightarrow$ Volatility \\
\hline & $2007-2014$ & $\left(\frac{-\pi}{2}, 0\right)$, In-phase & + & Volatility $\rightarrow$ p0p50 \\
\hline $\begin{array}{l}\text { Low } \\
\text { frequency }\end{array}$ & $1962-2014$ & $\left(0, \frac{\pi}{2}\right)$, In-phase & + & p0p50 $\rightarrow$ Volatility \\
\hline \multicolumn{5}{|c|}{ Good / (+) Volatility } \\
\hline \multirow[t]{2}{*}{$\begin{array}{l}\text { High } \\
\text { frequency }\end{array}$} & Period & Phase & $\begin{array}{c}\text { Sign of } \\
\text { co-movement }\end{array}$ & Causality \\
\hline & $1962-2014$ & $\left(0, \frac{\pi}{2}\right)$, In-phase & + & p0p50 $\rightarrow$ Volatility \\
\hline \multirow[t]{2}{*}{$\begin{array}{l}\text { Low } \\
\text { frequency }\end{array}$} & $1962-1989$ & $\left(\frac{-\pi}{2}, 0\right)$, In-phase & + & Volatility $\rightarrow$ p0p50 \\
\hline & $1990-2014$ & $\left(0, \frac{\pi}{2}\right)$, In-phase & + & p0p50 $\rightarrow$ Volatility \\
\hline \multicolumn{5}{|c|}{ Bad / (-) Volatility } \\
\hline \multirow[t]{3}{*}{$\begin{array}{l}\text { High } \\
\text { frequency }\end{array}$} & Period & Phase & $\begin{array}{c}\text { Sign of } \\
\text { co-movement }\end{array}$ & Causality \\
\hline & $1962-1988$ & $\left(0, \frac{\pi}{2}\right)$, In-phase & + & p0p50 $\rightarrow$ Volatility \\
\hline & $1989-2014$ & $\left(\frac{-\pi}{2}, 0\right)$, In-phase & + & Volatility $\rightarrow$ p0p50 \\
\hline $\begin{array}{l}\text { Low } \\
\text { frequency }\end{array}$ & $1962-2014$ & $\left(0, \frac{\pi}{2}\right)$, In-phase & + & p0p50 $\rightarrow$ Volatility \\
\hline
\end{tabular}


Table 14. Wavelet phase difference (Volatility, Net personal wealth held by p99p100)

\begin{tabular}{|c|c|c|c|c|}
\hline \multicolumn{5}{|c|}{ Volatility } \\
\hline $\begin{array}{l}\text { High } \\
\text { frequency }\end{array}$ & Period & Phase & $\begin{array}{c}\text { Sign of } \\
\text { co-movement }\end{array}$ & Causality \\
\hline & $1962-2005$ & $\left(0, \frac{\pi}{2}\right)$, In-phase & + & p99p100 $\rightarrow$ Volatility \\
\hline & 2006-2014 & $\left(\frac{-\pi}{2}, 0\right)$, In-phase & + & Volatility $\rightarrow$ p99p100 \\
\hline $\begin{array}{l}\text { Low } \\
\text { frequency }\end{array}$ & $1962-2014$ & $\left(0, \frac{\pi}{2}\right)$, In-phase & + & p99p100 $\rightarrow$ Volatility \\
\hline \multicolumn{5}{|c|}{ Good $/(+)$ Volatility } \\
\hline \multirow[t]{3}{*}{$\begin{array}{l}\text { High } \\
\text { frequency }\end{array}$} & Period & Phase & $\begin{array}{c}\text { Sign of } \\
\text { co-movement }\end{array}$ & Causality \\
\hline & $1962-1988$ & $\left(0, \frac{\pi}{2}\right)$, In-phase & + & p99p100 $\rightarrow$ Volatility \\
\hline & $1989-2014$ & $\left(\frac{-\pi}{2}, 0\right)$, In-phase & + & Volatility $\rightarrow$ p99p100 \\
\hline \multirow[t]{2}{*}{$\begin{array}{l}\text { Low } \\
\text { frequency }\end{array}$} & $1962-2000$ & $\left(\frac{-\pi}{2}, 0\right)$, In-phase & + & Volatility $\rightarrow$ p99p100 \\
\hline & 2001-2014 & $\left(0, \frac{\pi}{2}\right)$, In-phase & + & p99p100 $\rightarrow$ Volatility \\
\hline \multicolumn{5}{|c|}{ Bad / (-) Volatility } \\
\hline \multirow[t]{2}{*}{$\begin{array}{l}\text { High } \\
\text { frequency }\end{array}$} & Period & Phase & $\begin{array}{c}\text { Sign of } \\
\text { co-movement }\end{array}$ & Causality \\
\hline & $1962-2014$ & $\left(0, \frac{\pi}{2}\right)$, In-phase & + & p99p100 $\rightarrow$ Volatility \\
\hline $\begin{array}{l}\text { Low } \\
\text { frequency }\end{array}$ & $1962-2014$ & $\left(\frac{-\pi}{2}, 0\right)$, In-phase & + & Volatility $\rightarrow$ p99p100 \\
\hline
\end{tabular}


Figure 1. Causal relationship between Aggregate Output Volatility and Income Inequality measures
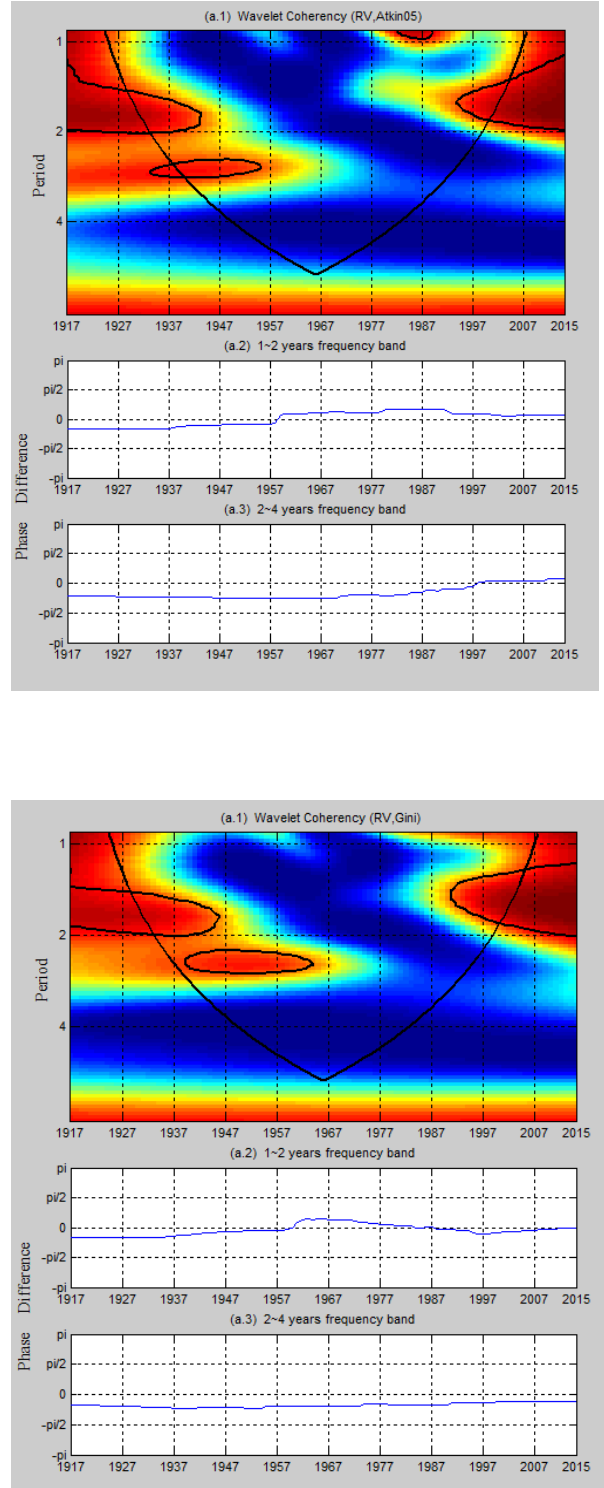
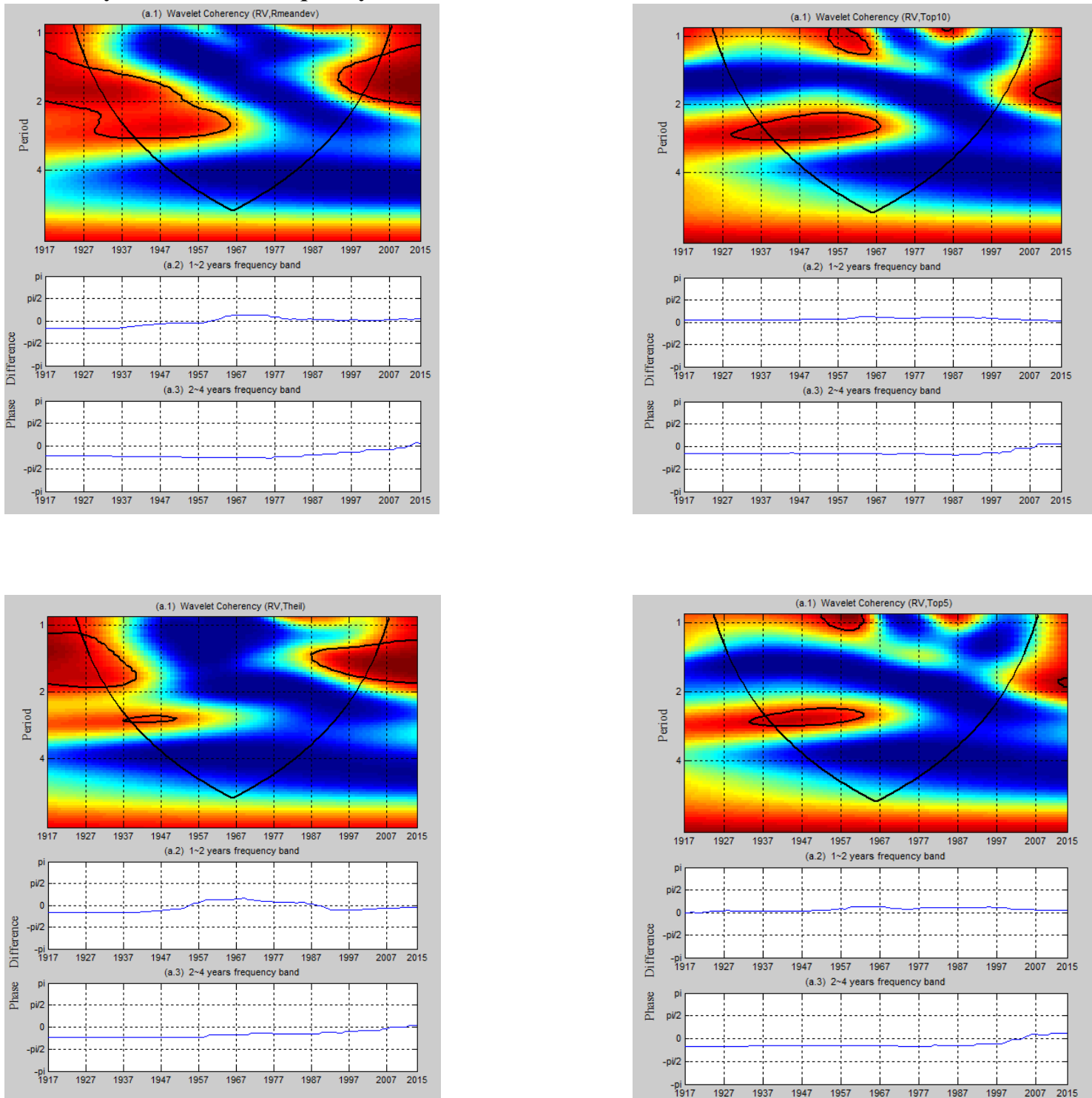

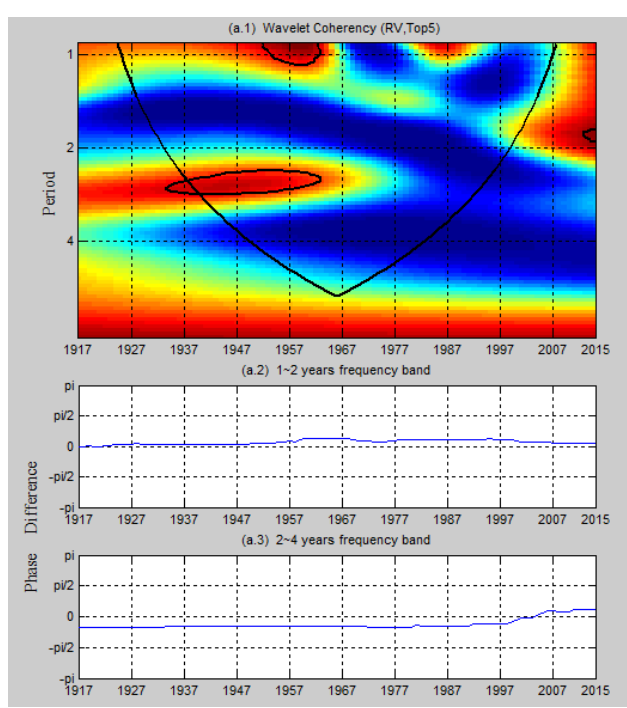



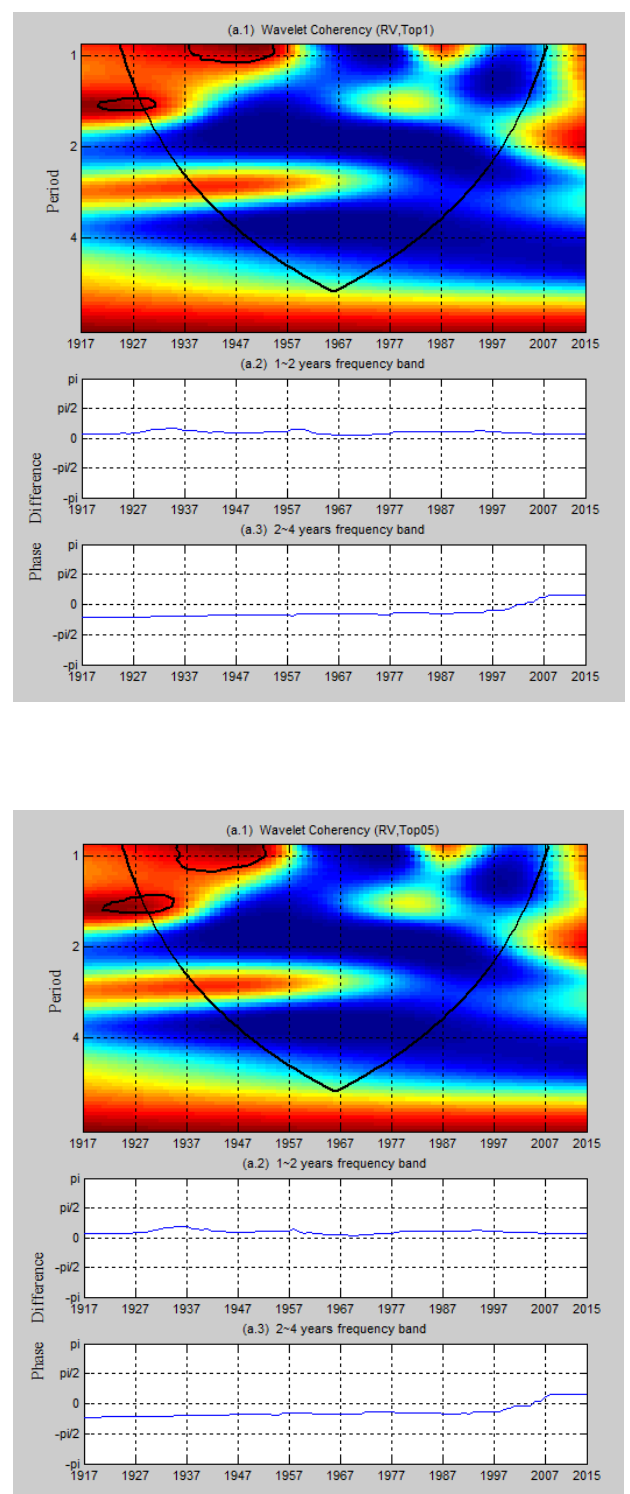
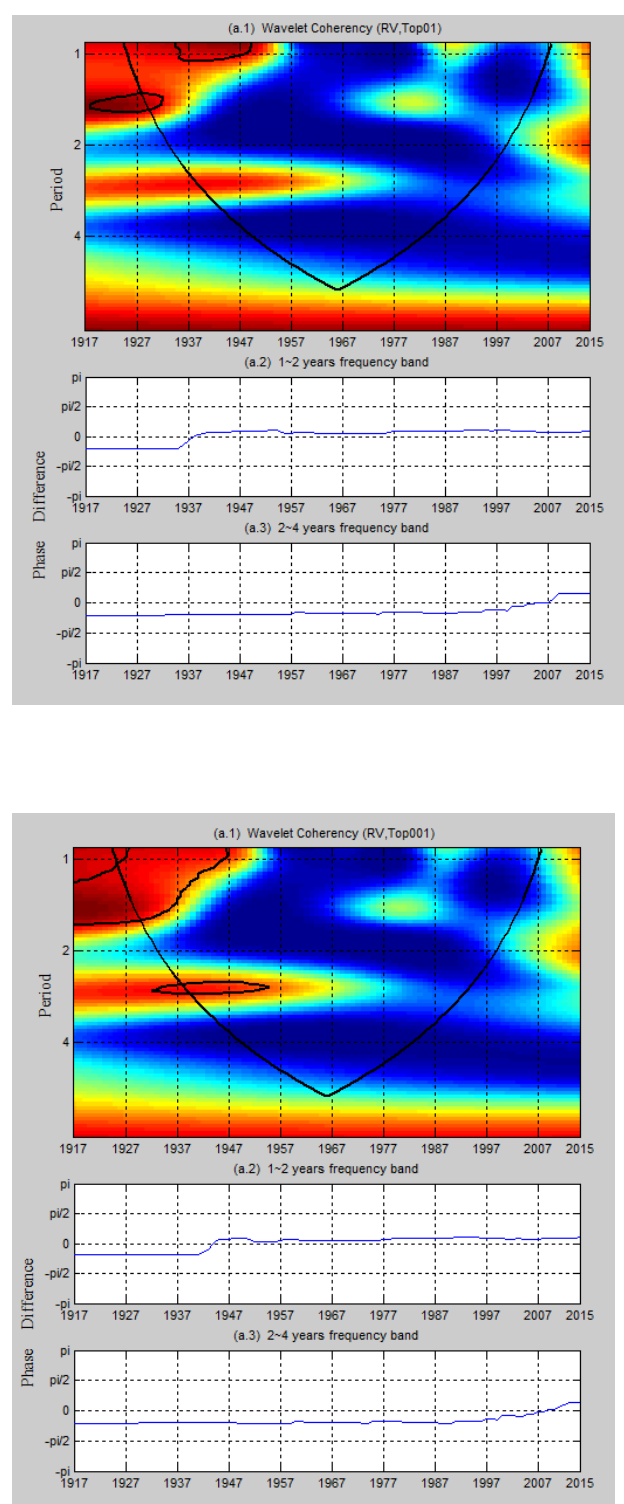

Note: Wavelet Coherency between the aggregate output volatility and income inequality measures. The black contour designates the $5 \%$ significance level estimated from the Monte Carlo simulations based on an ARMA $(1,1)$ Null. The colour code for power ranges from blue (low power) to red (high power). The $y$-axis refers to the frequencies (measured in years); the $\mathrm{x}$-axis refers to the time period over the period 1917-2015. 
Figure 2. Causal relationship between Positive Output Volatility and Income Inequality measures
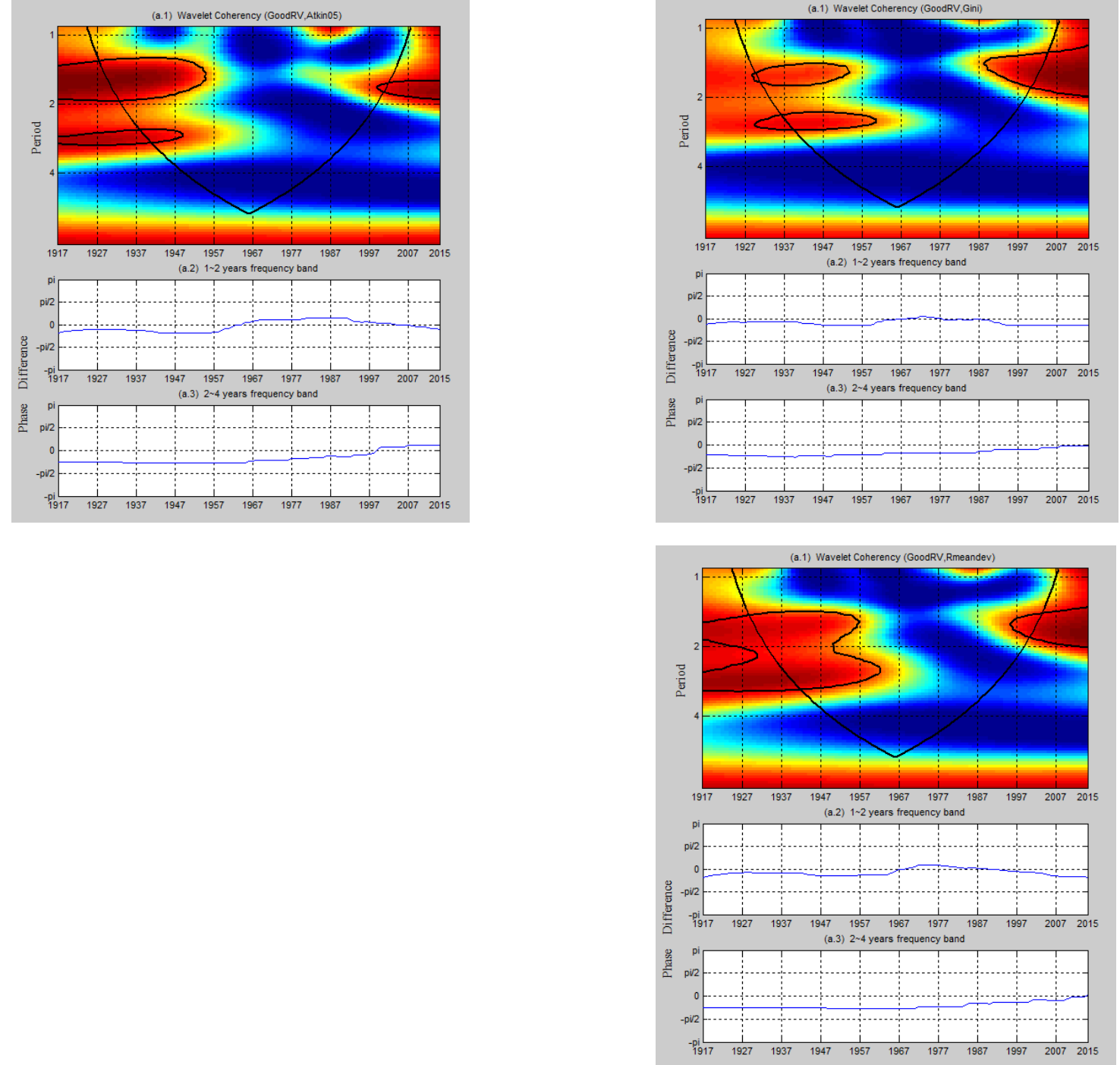

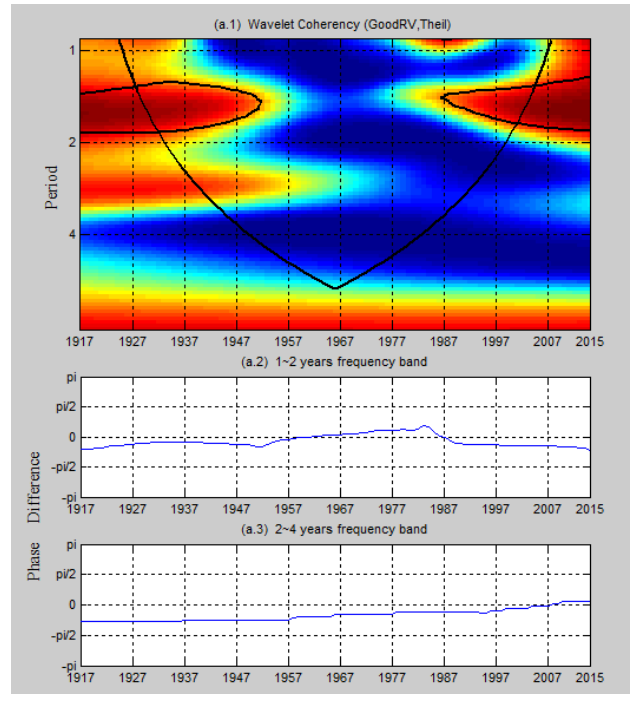



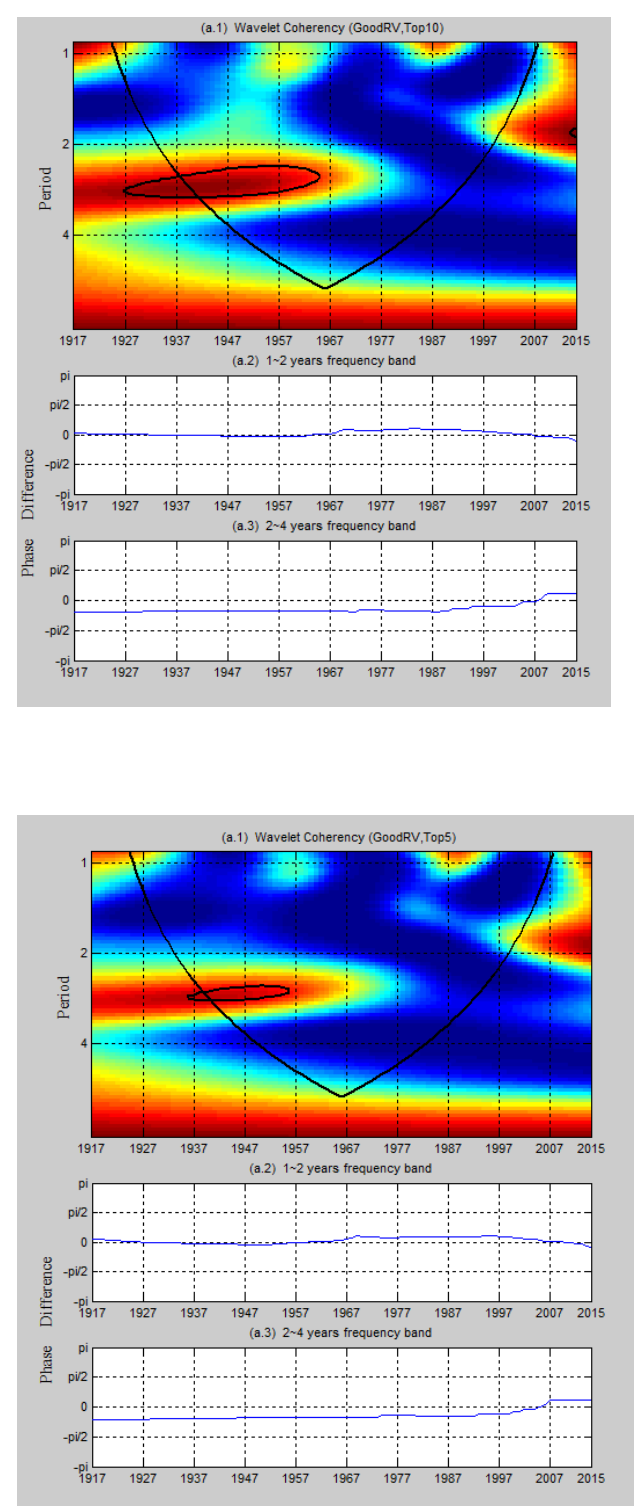
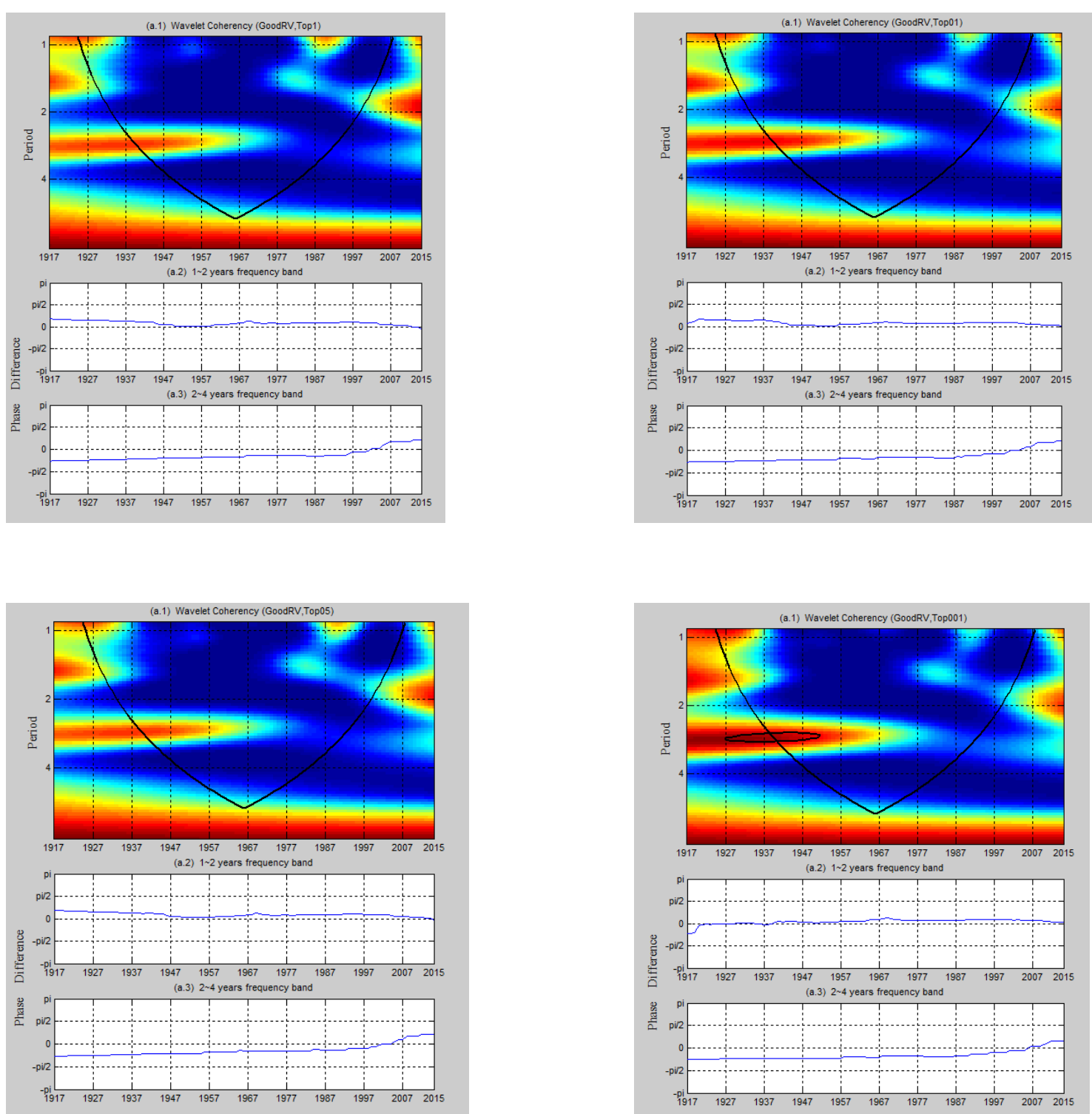

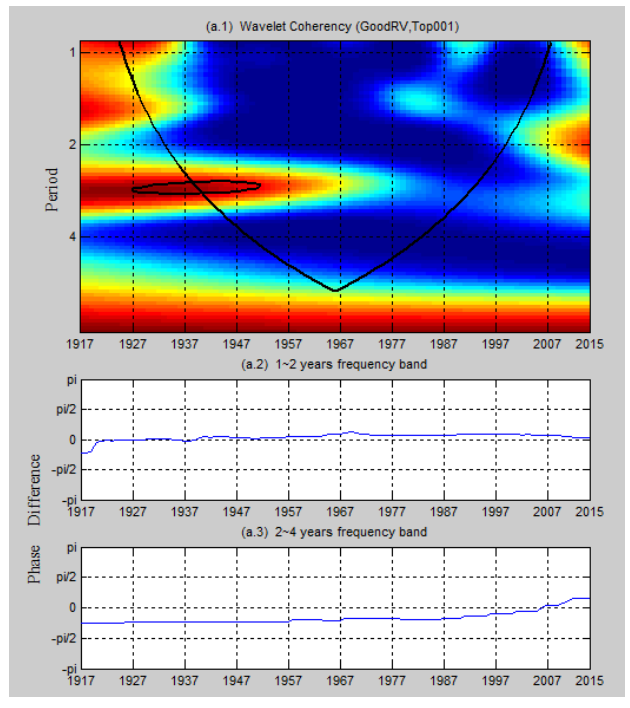


Note: Wavelet Coherency between the positive output volatility and income inequality measures.

The black contour designates the $5 \%$ significance

level estimated from the Monte Carlo simulations

based on an $\operatorname{ARMA}(1,1)$ Null. The colour code for power ranges from blue (low power) to red (high power). The $\mathrm{y}$-axis refers to the frequencies (measured in years); the $\mathrm{x}$-axis refers to the time period over the period 1917-2015. 
Figure 3. Causal relationship between Negative Output Volatility and Income Inequality measures
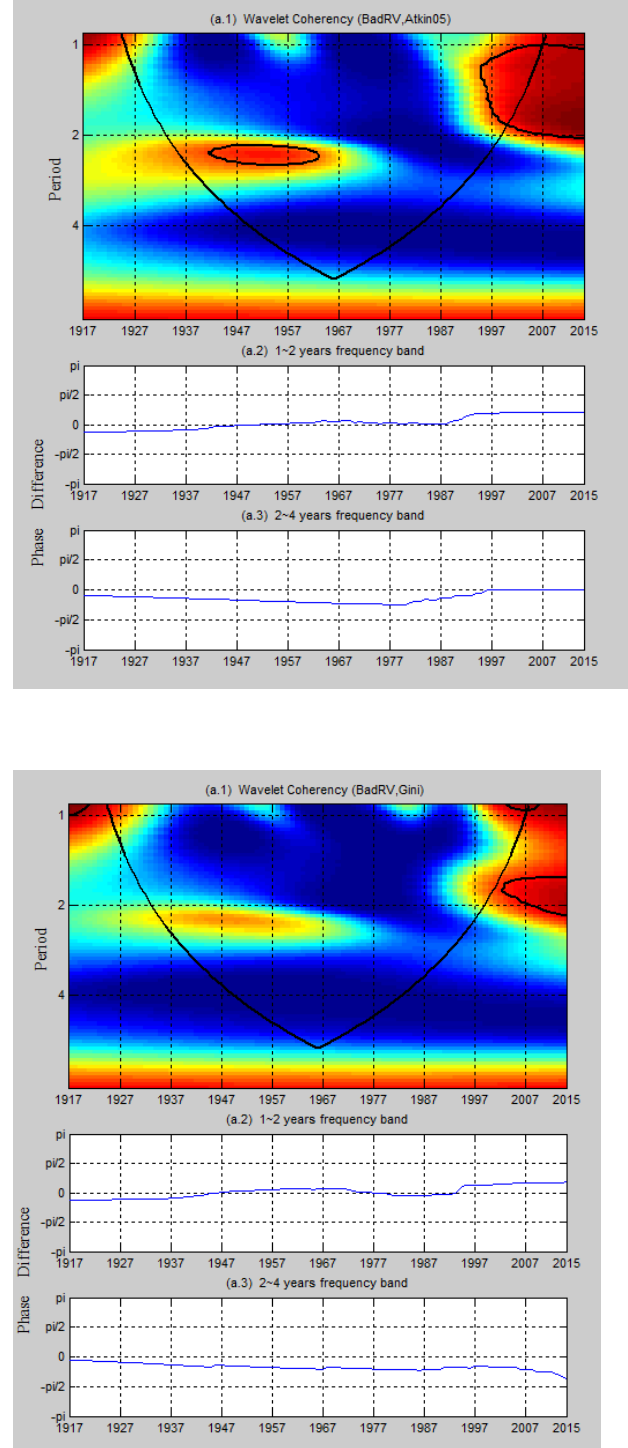
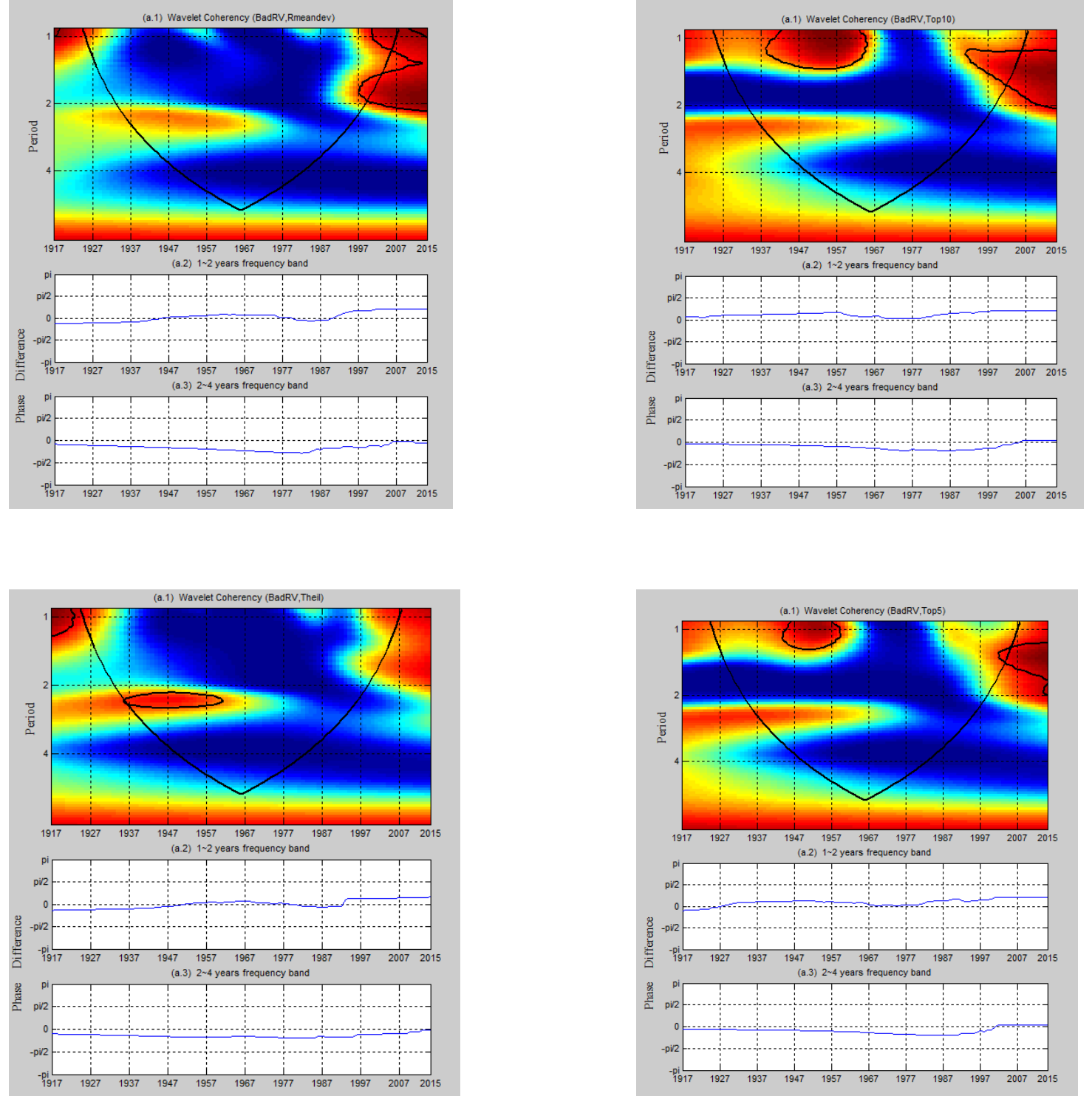

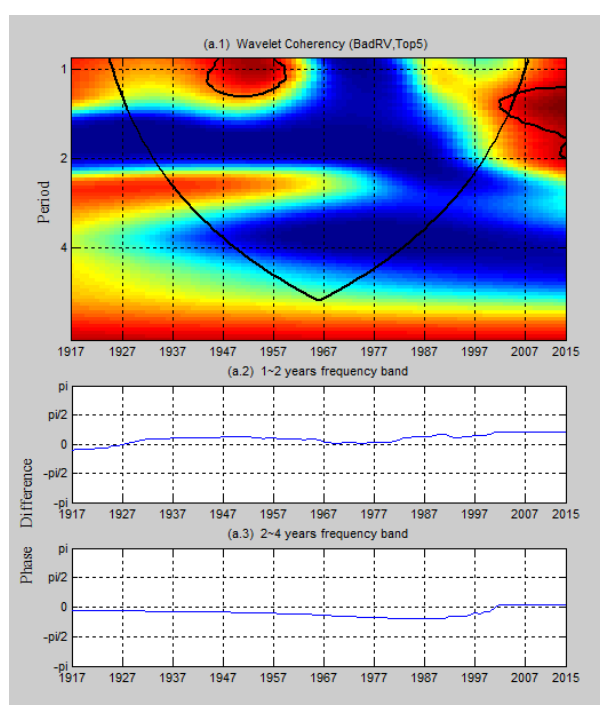



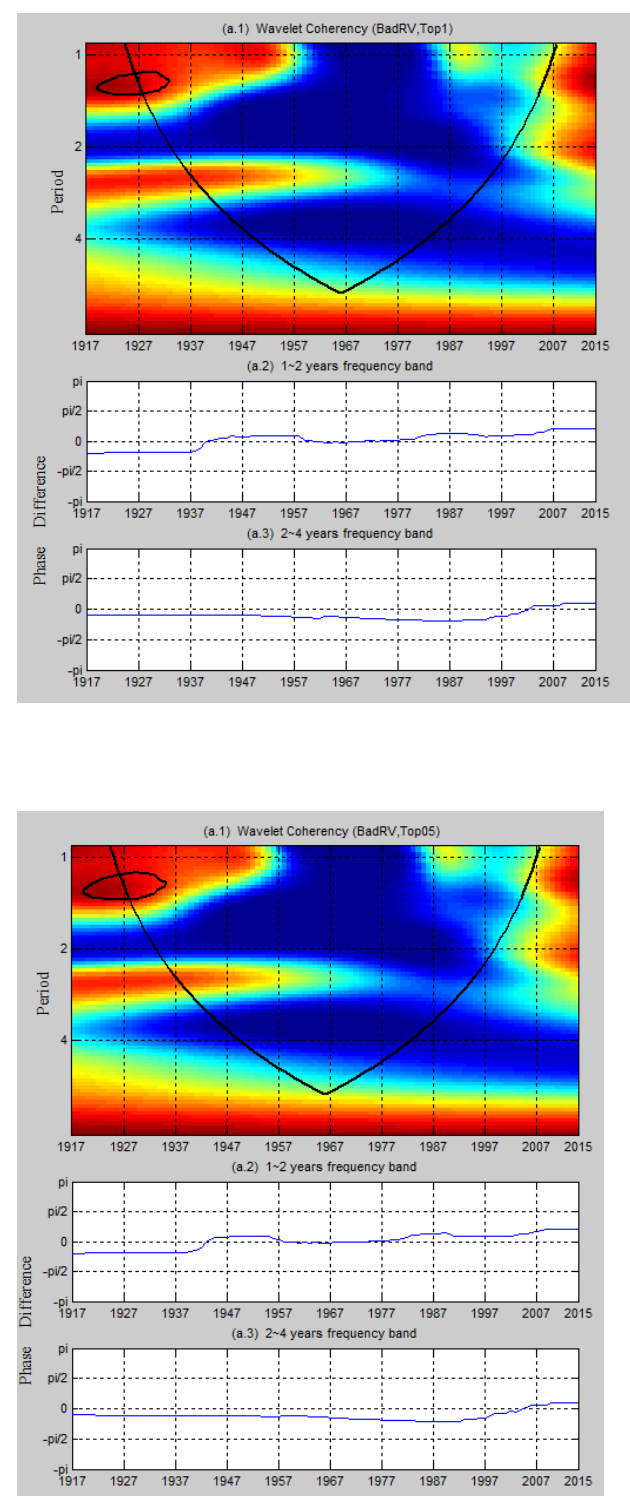

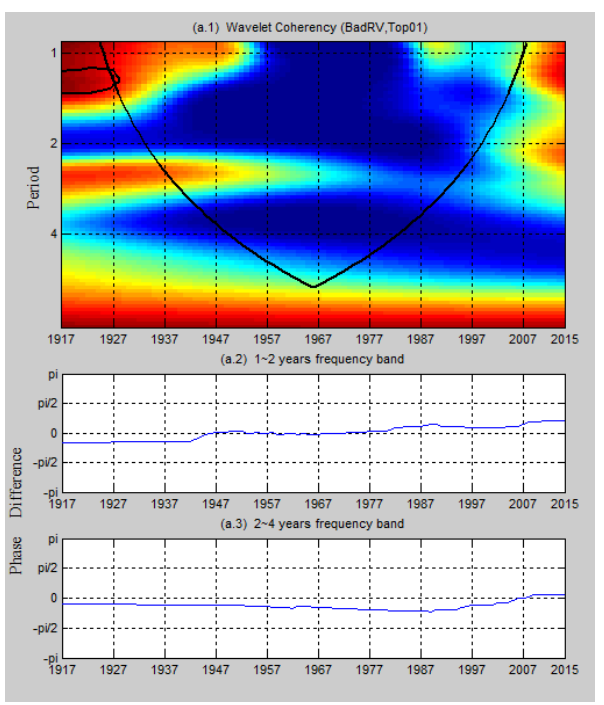

Note: Wavelet Coherency between the negative output volatility and income inequality measures. The black contour designates the $5 \%$ significance level estimated from the Monte Carlo simulations based on an ARMA $(1,1)$ Null. The colour code for power ranges from blue (low power) to red (high power). The $y$-axis refers to the frequencies (measured in years); the $\mathrm{x}$-axis refers to the time period over the period 1917-2015.

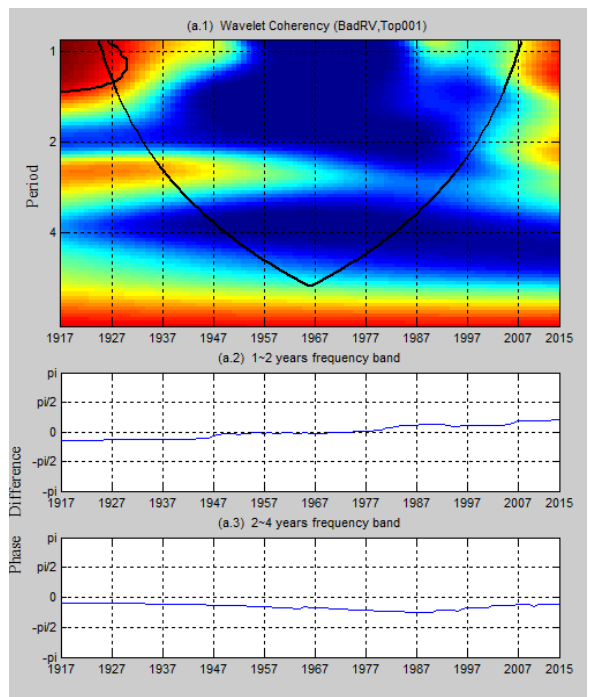


Figure 4. Causal relationship between Aggregate Output Volatility and Wealth Inequality measures
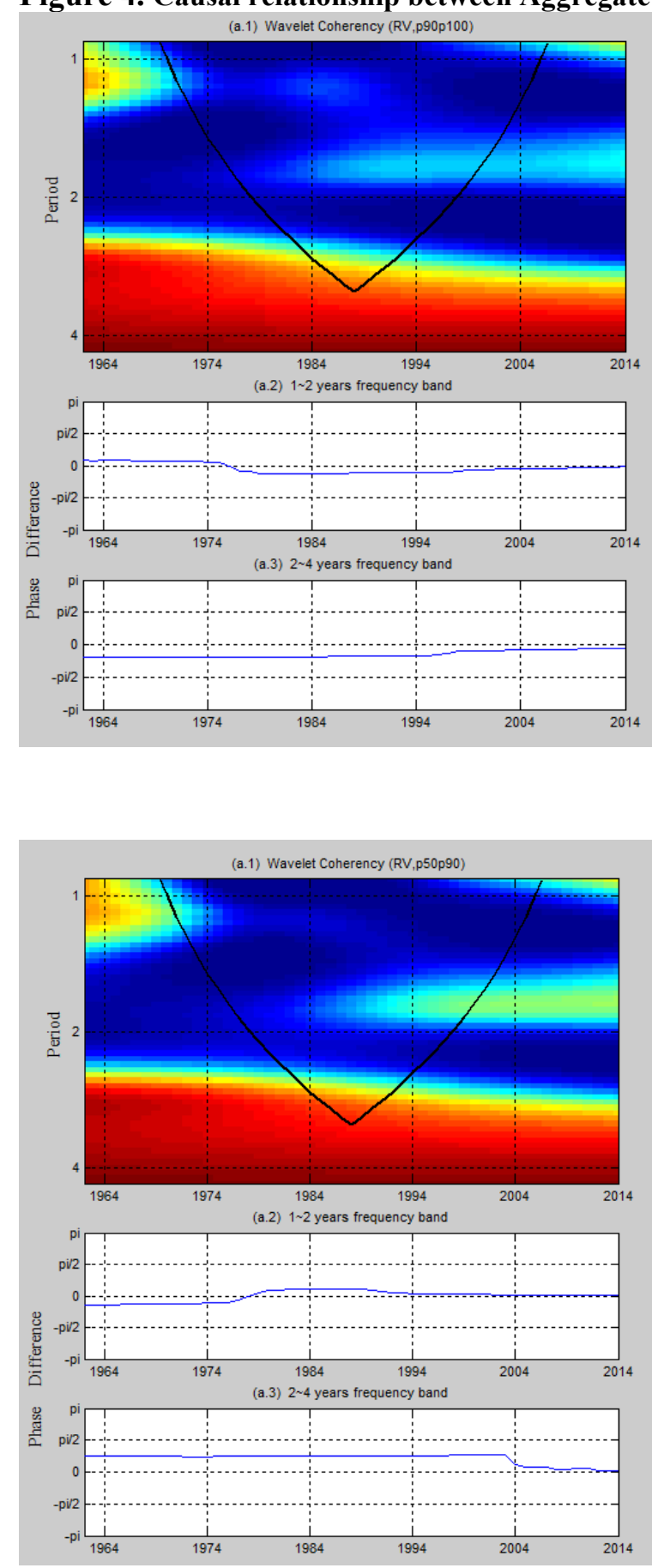

Note: Wavelet Coherency between the aggregate output volatility and wealth inequality measures. The black contour designates the $5 \%$ significance level estimated from the Monte Carlo simulations based on an $\operatorname{ARMA}(1,1)$ Null. The colour code for power ranges from blue (low power) to red (high power). The y-axis refers to the frequencies (measured in years); the x-axis refers to the time period over the period 1962-2014. 
Figure 5. Causal relationship between Positive Output Volatility and Wealth Inequality measures
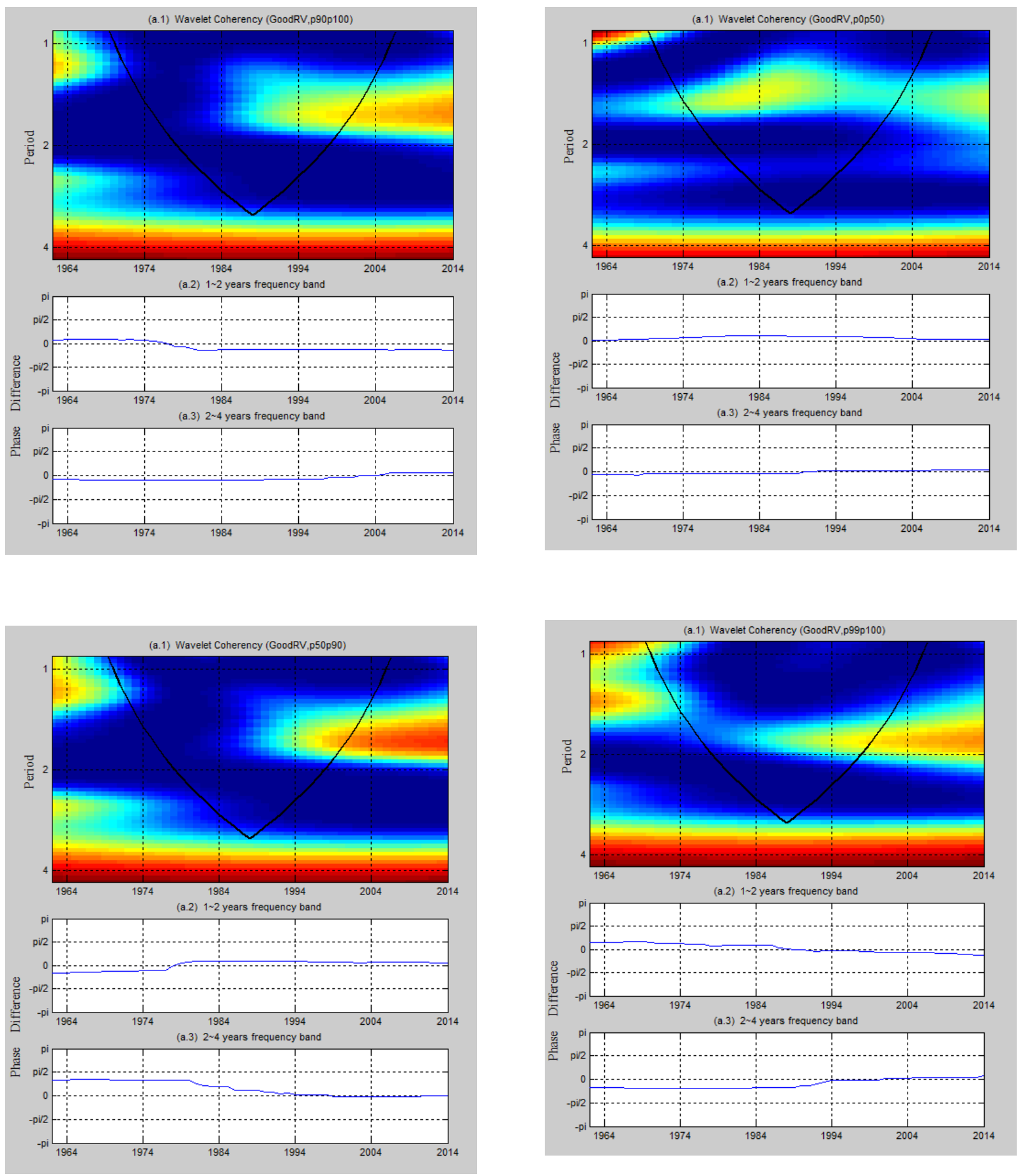

Note: Wavelet Coherency between the positive output volatility and wealth inequality measures. The black contour designates the $5 \%$ significance level estimated from the Monte Carlo simulations based on an ARMA $(1,1)$ Null. The colour code for power ranges from blue (low power) to red (high power). The y-axis refers to the frequencies (measured in years); the x-axis refers to the time period over the period 1962-2014. 
Figure 6. Causal relationship between Negative Output Volatility and Wealth Inequality measures
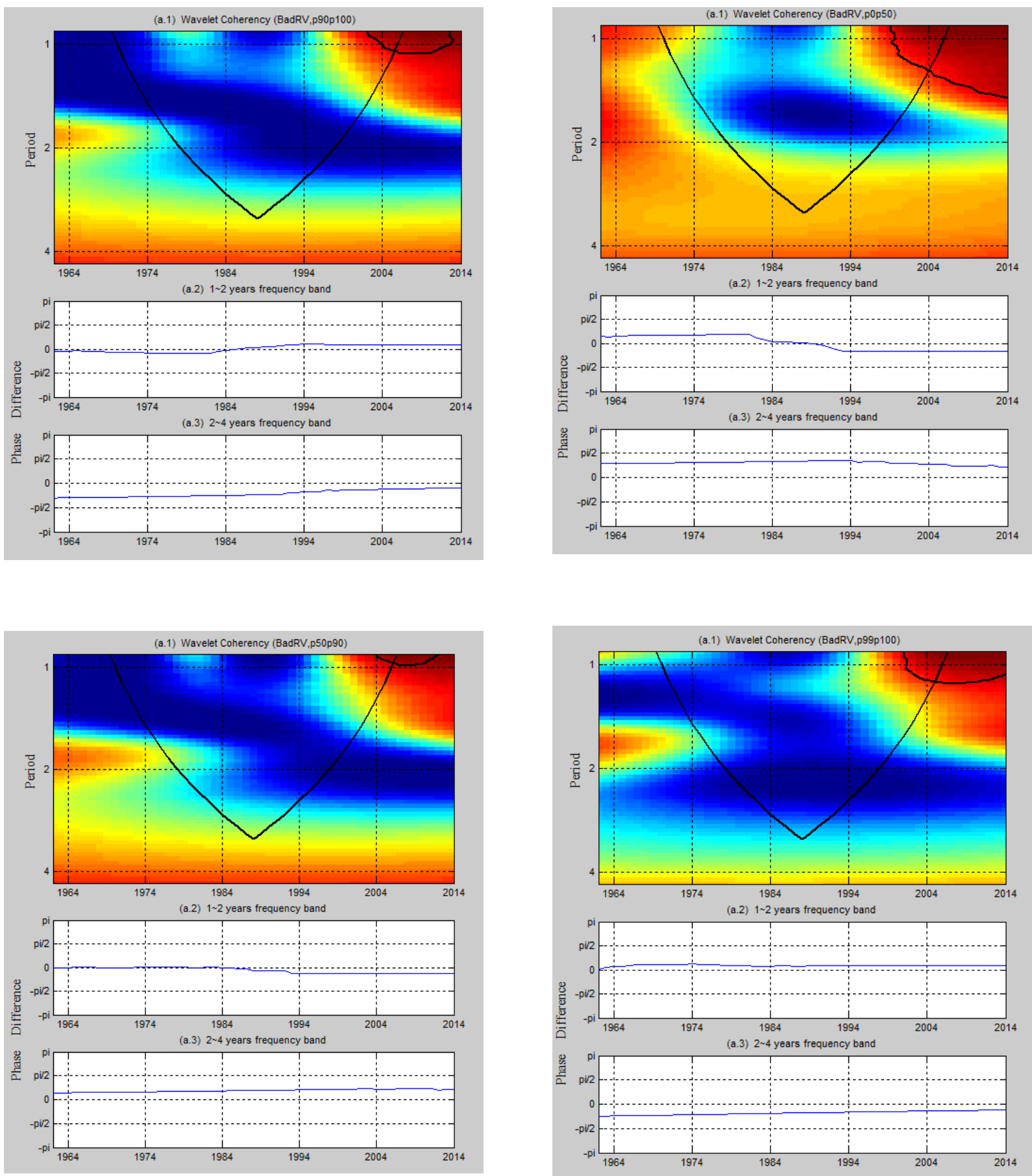

Note: Wavelet Coherency between the negative output volatility and wealth inequality measures. The black contour designates the $5 \%$ significance level estimated from the Monte Carlo simulations based on an $\operatorname{ARMA}(1,1)$ Null. The colour code for power ranges from blue (low power) to red (high power). The y-axis refers to the frequencies (measured in years); the x-axis refers to the time period over the period 1962-2014. 


\section{Figure 7. Short and Long Run Causality}

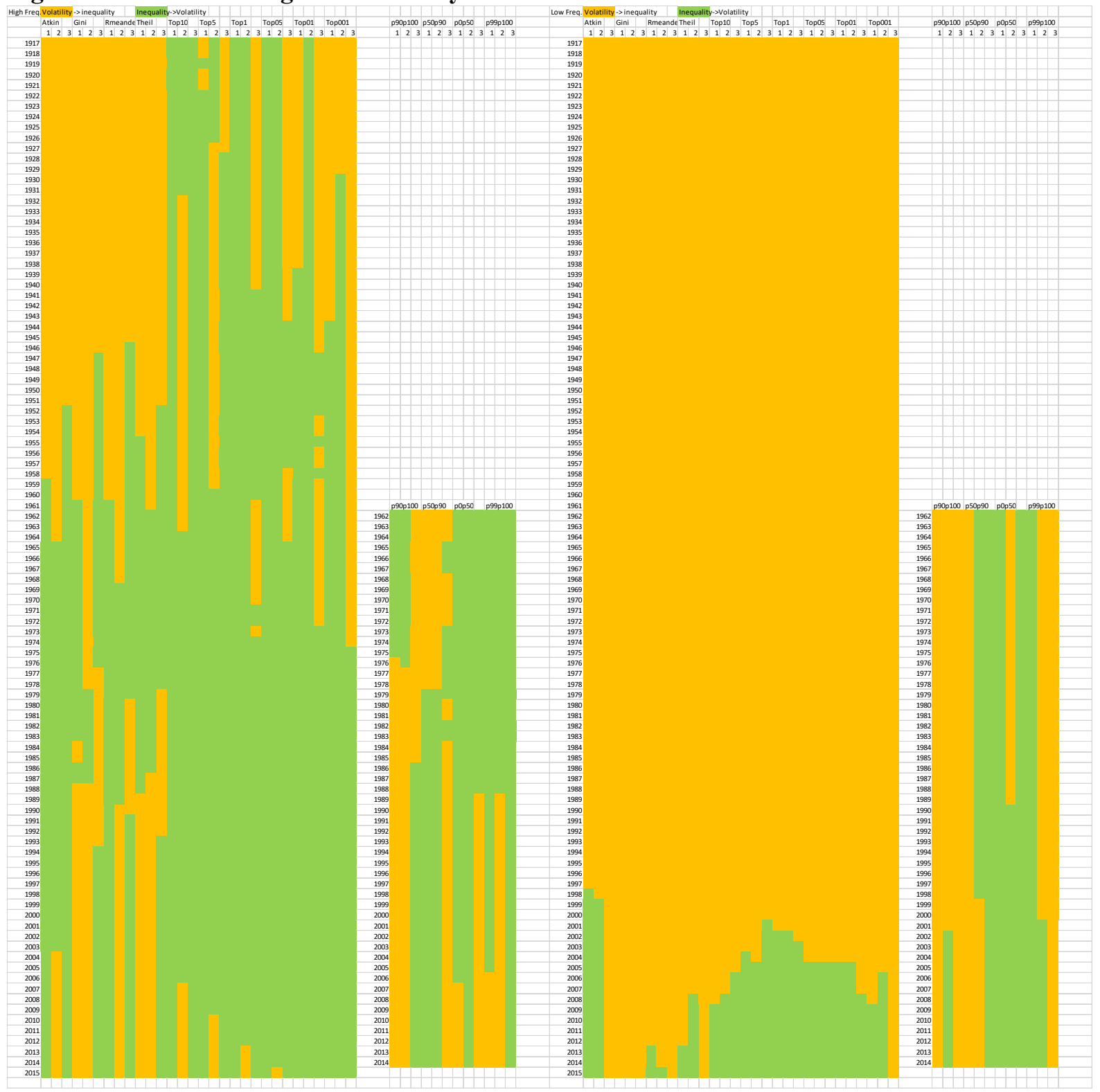

Note: First two figures from the left indicate the short run causality relationship between volatility and inequality. 1,2 and 3 indicate aggregate volatility, positive volatility and negative volatility. Orange colour indicates that the volatility leads and Green colour indicates that inequality leads. Third and fourth figures from the left show the long run causality. Y-axis indicates the year. 


\section{References}

Agénor, P. R. (2004). Macroeconomic adjustment and the poor: analytical issues and crosscountry evidence. Journal of Economic Surveys, 18(3), 351-408.

Aghion, P., Banerjee, A., \& Piketty, T. (1999). Dualism and macroeconomic volatility. The Quarterly Journal of Economics, 114(4), 1359-1397.

Aghion, P., Caroli, E., \& Garcia-Penalosa, C. (1999). Inequality and economic growth: the perspective of the new growth theories. Journal of Economic Literature, 1615-1660.

Aguiar-Conraria, L., Azevedo, N., \& Soares, M. J. (2008). Using wavelets to decompose the time-frequency effects of monetary policy. Physica A: Statistical Mechanics and its Applications, 387(12), 2863-2878.

Alesina, A., \& Perotti, R. (1996). Income distribution, political instability, and investment. European Economic Review, 40(6), 1203-1228.

Andersen, T. G., \& Teräsvirta, T. (2009). Realized volatility. In Handbook of financial time series (pp. 555-575). Springer, Berlin, Heidelberg.

Bloomfield, D. S., McAteer, R. J., Lites, B. W., Judge, P. G., Mathioudakis, M., \& Keenan, F. P. (2004). Wavelet phase coherence analysis: Application to a quiet-sun magnetic element. The Astrophysical Journal, 617(1), 623.

Bahmani-Oskooee, M., \& Motavallizadeh-Ardakani, A. (2018). On the Effects of Income Volatility on Income Distribution: Asymmetric Evidence from State Level Data in the US. Research in Economics. DOI: https://doi.org/10.1016/j.rie.2018.01.002.

Breen, R., \& García-Peñalosa, C. (2005). Income inequality and macroeconomic volatility: an empirical investigation. Review of Development Economics, 9(3), 380-398.

Calderón, C., \& Yeyati, E. L. (2009). Zooming In: From Aggregate Volatility to Income Distribution. Policy Research Working Paper. World Bank.

Caroli, E., \& García-Peñalosa, C. (2002). Risk aversion and rising wage inequality. Economics Letters, 77(1), 21-26.

Chauvet, L., Ferry, M., Patrick, G., Guillaumont Jeanneney, S., Tapsoba, S., \& Wagner, L. (2017). Volatility Widens Inequality. Could Aid and Remittances Help? (No. P158). FERDI.

Chauvet, L., \& Guillaumont, P. (2001). Aid and performance: a reassessment. Journal of Development Studies, 37(6), 66-92.

Chauvet, L., \& Guillaumont, P. (2009). Aid, volatility, and growth again: When aid volatility matters and when it does not. Review of Development Economics, 13(3), 452-463. 
Checchi, D., \& García-Peñalosa, C. (2004). Risk and the distribution of human capital. Economics Letters, 82(1), 53-61.

Corak, M., Lindquist, M. J., \& Mazumder, B. (2014). A comparison of upward and downward intergenerational mobility in Canada, Sweden and the United States. Labour Economics, 30, 185-200.

Eksi, O. (2017). Lower volatility, higher inequality: are they related?. Oxford Economic Papers, 69(4), 847-869.

Fan, Y., \& Gençay, R. (2010). Unit root tests with wavelets. Econometric Theory, 26(5), 13051331.

Galor, O., \& Zeira, J. (1993). Income distribution and macroeconomics. The Review of Economic Studies, 60(1), 35-52.

Gordon, R.J. (1986). The American Business Cycle: Continuity and Change. University of Chicago Press.

Guillaumont, P., \& Wagner, L. (2014). Aid Effectiveness for Poverty Reduction: Lessons from Cross-country Analyses, with a Special Focus on Vulnerable Countries. Revue d'économie du développement, 22(HS01), 217-261.

Grinsted, A., Moore, J. C., \& Jevrejeva, S. (2004). Application of the cross wavelet transform and wavelet coherence to geophysical time series. Nonlinear Processes in Geophysics, $11(5 / 6), 561-566$.

Hausmann, R., \& Gavin, M. (1996). Securing Stability and Growth in a Shock Prone Region: The Policy Challenge for Latin America (No. 6191). Inter-American Development Bank.

Hudgins, L., Friehe, C. A., \& Mayer, M. E. (1993). Wavelet transforms and atmopsheric turbulence. Physical Review Letters, 71(20), 3279.

Jeanneney, S. G., \& Kpodar, K. (2011). Financial development and poverty reduction: Can there be a benefit without a cost?. The Journal of development studies, 47(1), 143-163.

Konya, L., \& Mouratidis, C. (2006). An empirical analysis of the relationship between income inequality and growth volatility in 70 countries for 1960-2002. Applied Econometrics and International Development, 6(1), 5-16.

Laursen, T., \& Mahajan, S. (2005). Volatility, income distribution, and poverty. Managing Economic Volatility and Crises: A Practitioner's Guide, Cambridge University Press New York, 101-136.

Levy, A. (2002). A Note on Income Inequality and Macro-economic Volatility. Australian Economic Papers, 41(2), 233-238.

Leigh, A. (2007). How closely do top income shares track other measures of inequality?*. The Economic Journal, 117(524), F619-F633. 
Li, X. L., Chang, T., Miller, S. M., Balcilar, M., \& Gupta, R. (2015). The co-movement and causality between the US housing and stock markets in the time and frequency domains. International Review of Economics and Finance, 38, 220-233.

Loh, L. (2013). Co-movement of Asia-Pacific with European and US stock market returns: A cross-time- frequency analysis. Research in International Business and Finance, 29, $1-13$.

Nelson, C. R., \& Plosser, C. R. (1982). Trends and random walks in macroeconmic time series: some evidence and implications. Journal of monetary economics, 10(2), 139-162.

Omay, T., Gupta, R., \& Bonaccolto, G. (2017). The US real GNP is trend-stationary after all. Applied Economics Letters, 24(8), 510-514.

Ramey, G., \& Ramey, V. A. (1995). Cross-country evidence on the link between volatility and growth. The American Economic Review, 1138-1151.

Ramsey, J. B., \& Zhang, Z. (1996). The application of wave form dictionaries to stock market index data (pp. 189-205). Berlin: Springer.

Ramsey, J. B., \& Zhang, Z. (1997). The analysis of foreign exchange data using waveform dictionaries. Journal of Empirical Finance, 4(4), 341-372.

Roueff, F., \& Sachs, R. (2011). Locally stationary long memory estimation. Stochastic Processes and Their Applications, 121, 813-844.

Tiwari, A. K., Mutascu, M., \& Andries, A. M. (2013). Decomposing time-frequency relationship between producer price and consumer price indices in Romania through wavelet analysis. Economic Modelling, 31, 151-159.

Torrence, C., \& Compo, G. P. (1998). A practical guide to wavelet analysis. Bulletin of the American Meteorological Society, 79(1), 61-78. 